\title{
A HIF1a-Dependent Pro-Oxidant State Disrupts Synaptic Plasticity and Impairs Spatial Memory in Response to Intermittent Hypoxia
}

\author{
Alejandra Arias-Cavieres, ${ }^{1}$ Maggie A. Khuu, ${ }^{3}$ Chinwendu U. Nwakudu, ${ }^{3}$ Jasmine E. Barnard, ${ }^{3}$ \\ Gokhan Dalgin, ${ }^{4}$ and Alfredo J. Garcia III, ${ }^{1,2,3}$
}

https://doi.org/10.1523/ENEURO.0024-20.2020

${ }^{1}$ Institute for Integrative Physiology, The University of Chicago, Chicago, IL 60637, ${ }^{2}$ Grossman Institute for Neuroscience, Quantitative Biology and Human Behavior, The University of Chicago, Chicago, IL 60637, ${ }^{3}$ Department of Medicine, Section of Emergency Medicine, The University of Chicago, Chicago, IL 60637, and ${ }^{4}$ Department of Medicine Section of Adult and Pediatric Endocrinology, Diabetes, and Metabolism, The University of Chicago, Chicago, IL 60637

\begin{abstract}
Sleep apnea causes cognitive deficits and is associated with several neurologic diseases. Intermittent hypoxia $(\mathrm{IH})$ is recognized as a principal mediator of pathophysiology associated with sleep apnea, yet the basis by which $\mathrm{IH}$ contributes to impaired cognition remains poorly defined. Using a mouse model exposed to $\mathrm{IH}$, this study examines how the transcription factor, hypoxia inducible factor 1a (HIF1a), contributes to disrupted synaptic physiology and spatial memory. In wild-type mice, impaired performance in the Barnes maze caused by IH coincided with a loss of NMDA receptor (NMDAr)-dependent long-term potentiation (LTP) in area CA1 and increased nuclear HIF1a within the hippocampus. IH-dependent HIF1a signaling caused a two-fold increase in expression of the reactive oxygen species (ROS) generating enzyme NADPH oxidase 4 (NOX4). These changes promoted a pro-oxidant state and the downregulation of GluN1 within the hippocampus. The IH-dependent effects were not present in either mice heterozygous for Hif1a $\left(\mathrm{HIF1a}^{+/-}\right)$or wild-type mice treated with the antioxidant manganese (III) tetrakis(1-methyl-4-pyridyl) porphyrin (MnTMPyP). Our findings indicate that HIF1adependent changes in redox state are central to the mechanism by which $\mathrm{IH}$ disrupts hippocampal synaptic plasticity and impairs spatial memory. This mechanism may enhance the vulnerability for cognitive deficit and lower the threshold for neurologic diseases associated untreated sleep apnea.
\end{abstract}

Key words: hypoxia inducible factor; NADPH oxidase; NMDA receptor; oxidative stress; sleep apnea

\section{Significance Statement}

Sleep apnea is associated with cognitive decline and neurologic disease. Intermittent hypoxia (IH), a hallmark consequence of sleep apnea, yet the mechanisms by which $\mathrm{IH}$ affects cognition is poorly understood. We show that a pro-oxidant state produced by HIF1a is a central factor causing IH-dependent impairment to spatial memory and synaptic plasticity. This work identifies potential targets for intervention in mitigating cognitive decline associated with sleep apnea.

\section{Introduction}

The hippocampus is widely regarded for its importance in learning and memory and is frequently identified as a brain structure impacted by sleep apnea (Sforza et al.,

Received January 24, 2020; accepted May 15, 2020; First published June 3, 2020.

The authors declare no competing financial interests.
2016; Cha et al., 2017; Macey et al., 2018; Song et al., 2018). As cognitive decline is a recognized comorbidity of sleep apnea (Wallace and Bucks, 2013; Varga et al., 2014;

Author contributions: A.A.-C. and A.J.G. designed research; A.A.-C., M.A.K., C.U.N., J.E.B., G.D., and A.J.G. performed research; A.J.G. contributed unpublished reagents/analytic tools; A.A.-C., M.A.K., C.U.N., J.E.B., G.D., and A.J.G. analyzed data; A.A.-C., M.A.K., and A.J.G. wrote the paper. 
Gildeh et al., 2016; Devita et al., 2017a,b; Leng et al., 2017), changes to hippocampal physiology may have a significant role in disrupting cognition. Intermittent hypoxia $(\mathrm{IH})$ is a hallmark of the sleep apnea and impairs spatial learning and memory (Row et al., 2002; Gozal et al., 2003). These impairments coincide with weakened synaptic plasticity in area CA1 of the hippocampus (Goldbart et al., 2003; Payne et al., 2004; Xie et al., 2010; Zhang et al., 2012; Wall et al., 2014) and the production of oxidative stress in the brain (Nair et al., 2011; Chou et al., 2013). Impaired synaptic plasticity and oxidative stress have been implicated in causing $\mathrm{IH}$-dependent deficits to cognition, but the mechanistic basis by which IH impairs learning and memory remains elusive.

The transcription factor, hypoxia inducible factor $1 \mathrm{a}$ (HIF1a) is a critical mediator of cellular adaptations to hypoxia, and is capable of promoting the generation of reactive oxygen species (ROS) that can lead to oxidative stress (Semenza and Prabhakar, 2015). IH increases HIF1a in the hippocampal formation (Chou et al., 2013; Wall et al., 2014). However, the role of $\mathrm{IH}$-dependent HIF1a signaling on changes to the neurophysiological processes underlying cognition remains poorly understood. HIF1a signaling may have an important protective pro-survival role in the brain preserving function in response to the hypoxia experienced during $\mathrm{IH}$. Alternatively, HIF1a may serve as a pro-oxidant transcription factor leading to oxidative stress and impaired neurophysiology. Here, we seek to resolve the role of HIF1a in IH-dependent changes to cognition and the synaptic plasticity. Our experiments demonstrate that enhanced HIF1a signaling promotes a pro-oxidant condition that impairs NMDA receptor (NMDAr)-dependent synaptic plasticity at the local circuit level and contributes deficits in spatial memory.

\section{Materials and Methods Study approval}

In accordance with National Institutes of Health guidelines, all animal procedures were performed in accordance with the University of Chicago animal care committee's regulations.

This work was supported by National Institutes of Health Grants PO $1 \mathrm{HL}$ 144454 and R01 NS10742101 (to A.J.G.) and by a grant from The BSD Office of Diversity \& Inclusion at The University of Chicago (A.J.G.). G.D. was also supported by The University of Chicago Diabetes Research Center Grant P30 DK020595.

Acknowledgements: We thank Dr. Nanduri Prabhakar and Dr. Gregg Semenza for the provision of the HIF1a ${ }^{+/-}$mouse line. We also thank Dr. N. Prabhakar for the sound advice throughout the course of the study and the preparation of this manuscript. This article was first published as a preprint: A. Arias-Cavieres, M. A. Khuu, C. U. Nwakudu, J. E. Barnard, G. Dalgin, A. J. Garcia III (2019) A role for hypoxia inducible factor 1a (HIF1a) to intermittent hypoxia-dependent changes in spatial memory and synaptic plasticity. bioRxiv, https://doi.org/10.1101/595975.

Correspondence should be addressed to Alfredo J. Garcia at ajgarcia3@ uchicago.edu.

https://doi.org/10.1523/ENEURO.0024-20.2020

Copyright (C) 2020 Arias-Cavieres et al.

This is an open-access article distributed under the terms of the Creative Commons Attribution 4.0 International license, which permits unrestricted use, distribution and reproduction in any medium provided that the original work is properly attributed.

\section{Animals}

Animals were housed in AAALAC-approved facilities with a 12/12 h light/dark cycle and given ad libitum access to food and water. Experiments were performed on wild-type mice and HIF1a ${ }^{+/-}$(lyer et al., 1998; Peng et al., 2006) from both sexes (Postnatal day 50 to 80). Unless explicitly stated, no sex-based differences were observed throughout the experiments conducted. All animals were maintained on a C57BL/6 background. Automated genotyping was performed independently by a commercial service (Transnetyx Inc).

\section{IH exposure}

Male and female mice were exposed to chronic $\mathrm{IH}$ for 10 consecutive days $\left(\mathrm{IH}_{10}\right)$. In brief, as previously described (Peng and Prabhakar, 2003), the $\mathrm{IH}_{10}$ paradigm was performed in a special chamber during the light cycle and lasted $8 \mathrm{~h} / \mathrm{d}$ (i.e., $80 \mathrm{lH}$ cycles/d). A single hypoxic cycle was achieved by flowing $100 \% \mathrm{~N}_{2}$ into the chamber for $\sim 60 \mathrm{~s}$ (nadir $\mathrm{O}_{2}$ reached $4.5 \pm 1.5 \%$ ) and followed immediately by an air break ( $\left.21 \% \mathrm{O}_{2} ; 300 \mathrm{~s}\right)$.

In a subset of animals used for behavioral experiments, manganese (III) tetrakis(1-methyl-4-pyridyl) porphyrin (MnTMPyP; Enzo Life Sciences, catalog \#ALX-430-070) was administered via intraperitoneal injection at the beginning of each day before exposure to $\mathrm{IH}$. Previous reports have indicated that dose of MnTMPyP at either $5 \mathrm{mg} / \mathrm{kg}$ (Peng et al., 2006) or $15 \mathrm{mg} / \mathrm{kg}$ (Khuu et al., 2019) can mitigate the effects of $\mathrm{IH}$ in the nervous system. Therefore, the smaller dose $(5 \mathrm{mg} / \mathrm{kg}, n=9$ mice $)$ and the larger dose $(15 \mathrm{mg} / \mathrm{kg}, n=3$ mice) were used but no differences were evident between dosage groups; and therefore, the data at the two concentrations were pooled.

\section{Barnes maze}

The Barnes maze was performed using a custom made opaque white circular acrylic platform $(92.4 \mathrm{~cm}$ in diameter) with 20 equidistant holes $(5.08 \mathrm{~cm}$ in diameter and $2.54 \mathrm{~cm}$ from the edge). The platform was elevated (30 cm from the floor) ground and surrounded by four identical walls $(27.94 \mathrm{~cm}$ high). By default, each hole was closed with a fixed piece of opaque acrylic that could be removed to lead to a dark exit box. Lighting was achieved through diffuse overhead fluorescent lighting such that all holes were equally lit. An overhead camera was suspended above the maze allowing for video tracking. Data collection and post hoc analysis was performed using CinePlex Video Tracking System (Plexon).

As previously described (Christakis et al., 2012), the task was performed using a 4-d protocol consisting of one training trial per day for three consecutive days and a probe trial on the fourth day. Barnes maze began on the seventh day of $\mathrm{IH}_{10}$ exposure with respective controls run at the same time. In $\mathrm{IH}$ mice, all training trials and the probe trial were conducted before $\mathrm{IH}$ exposure on days 7-10. For the training trials, all, but one of the holes (exit hole), were closed. Closed holes were defined as false 
exits in the training and probe trials. An exit box with a small ramp was placed directly underneath the exit hole. Animals were given a maximum of $6 \mathrm{~min}$ to locate the exit. If the mouse found and entered the exit before the 6-min mark, the trial ended. The time of exit was reported as total latency for the trial. If the mouse was unable to locate the exit by $6 \mathrm{~min}$, they were gently guided to the exit and total latency for the trial was reported as $360 \mathrm{~s}$. At end of each trials, the mouse was promptly returned to its home cage. During the probe trial, all holes were closed, and the animal was given 6 min to explore the maze. Latency to initial entry and distance to initial entry into the exit zone were reported. All subjects entered the exit zone during the probe trial. The total number of entries for each false exit and the exit were recorded and used to calculate entry probability.

Entry probability for each false exit and the exit zone during the probe trial was calculated by the following:

$$
E P_{n}=100 \% \times \frac{x_{n}}{x_{\text {total }}},
$$

where $E P_{n}=$ entry probability for the exit zone; $x_{n}=$ number of entries into hole $\mathrm{n}$; and $x_{\text {total }}=$ sum of entries into exit zone and false exits.

The entire arena was sanitized in-between trials. Following the end of behavioral testing, $\mathrm{IH}$ animals were immediately placed into the $\mathrm{IH}$ chamber for exposure.

\section{Slice preparation}

As previously described (Khuu et al., 2019), acute coronal hippocampal slices were prepared from mice unexposed to $\mathrm{IH}$ or from mice exposed to $\mathrm{IH}$ for $10 \mathrm{~d}$. Tissue harvest occurred within 1-2 d following $\mathrm{IH}_{10}$. Mice were anesthetized with isoflurane and euthanized via rapid decapitation. The cerebrum was immediately harvested and blocked, rinsed with cold artificial CSF (aCSF), and mounted for vibratome sectioning. The mounted brain tissue was submerged in aCSF $\left(4^{\circ} \mathrm{C}\right.$; equilibrated with $95 \%$ $\mathrm{O}_{2}, 5 \% \mathrm{CO}_{2}$ ) and coronal cortico-hippocampal brain slices $(350 \mu \mathrm{m}$ thick) were prepared. Slices were then immediately transferred into a holding chamber containing aCSF equilibrated with $95 \% \mathrm{O}_{2}, 5 \% \mathrm{CO}_{2}$ (at $20.5 \pm 1^{\circ} \mathrm{C}$ ). Slices were allowed to recover for a minimum of one hour before recording and used up to eight hours following tissue harvest. The composition of aCSF was as following: $118 \mathrm{~mm} \mathrm{NaCl}, 10 \mathrm{~mm}$ glucose, $20 \mathrm{~mm}$ sucrose, $25 \mathrm{~mm}$ $\mathrm{NaHCO}_{3}, 3.0 \mathrm{~mm} \mathrm{KCl}, 1.5 \mathrm{~mm} \mathrm{CaCl}, 1.0 \mathrm{~mm} \mathrm{NaH}{ }_{2} \mathrm{PO}_{4}$, and $1.0 \mathrm{~mm} \mathrm{MgCl}_{2}$.

\section{Extracellular recording of the field EPSP (fEPSP)}

For electrophysiological recordings, slices were transferred to a recording chamber with recirculating aCSF $\left(30.5 \pm 1{ }^{\circ} \mathrm{C}\right.$, equilibrated with $95 \% \mathrm{O}_{2}$ and $\left.5 \% \mathrm{CO}_{2}\right)$ and allowed $15 \mathrm{~min}$ to acclimate to the recording environment. The fEPSP in the CA1 was evoked by electrical stimulation. The stimulation electrode was positioned in Schaffer Collateral and the recording electrode (1-2 $M \Omega$ ) was placed into the stratum radiatum of the CA1. The intensity of the electrical current $(100-400 \mu \mathrm{A} ; 0.1-0.2 \mathrm{~ms}$ in duration) was set to the minimum amount of current required to generate $\sim 50 \%$ of the maximal initial slope $\left(\mathrm{m}_{\mathrm{i}}\right)$ of the fEPSP. The current stimulus used to examine the unpotentiated fEPSP was evoked at $700 \mu \mathrm{A}$ (a stimulus intensity that evoked the maximal fEPSP amplitude in aCSF for all slices) and examined in aCSF, $\mathrm{Mg}^{2+}$-free aCSF, and $\mathrm{Mg}^{2+}$-free aCSF with $20 \mu \mathrm{M}$ AP5 (Sigma-Aldrich). The composition of $\mathrm{Mg}^{2+}$-free aCSF: $119.5 \mathrm{~mm} \mathrm{NaCl}, 10 \mathrm{~mm}$ glucose, $20 \mathrm{~mm}$ sucrose, $25 \mathrm{~mm} \mathrm{NaHCO}_{3}, 3.0 \mathrm{~mm} \mathrm{KCl}, 1.5$ $\mathrm{mM} \mathrm{CaCl} 2$, and $1.0 \mathrm{~mm} \mathrm{NaH}_{2} \mathrm{PO}_{4}$. The $\mathrm{NaCl}$ was increased to $119.5 \mathrm{~mm}$ to keep osmolarity from changing when switching from aCSF to $\mathrm{Mg}^{2+}$-free aCSF. The fEPSP was evoked every $20 \mathrm{~s}$. After $10 \mathrm{~min}$ of recording the baseline fEPSP, long-term potentiation (LTP) was induced using high-frequency stimulation (HFS) or theta burst stimulation (TBS). HFS consisted four 500-ms trains of stimuli $(100 \mathrm{~Hz})$ given at $30-\mathrm{s}$ intervals. TBS consisted of four trains of 10 bursts at $5 \mathrm{~Hz}$, each burst was comprised of four pulses at $100 \mathrm{~Hz}$. The fEPSP slope was normalized to baseline values (before HFS).

All recordings were made using the Multiclamp 700B (Molecular Devices: https://www.moleculardevices.com/ systems/conventional-patch-clamp/multiclamp-700bmicroelectrode-amplifier). Acquisition and post hoc analyses were performed using the Axon pCLAMP10 software suite (Molecular Devices: https://www.moleculardevices.com/ system/axon-conventional-patch-clamp/pclamp-11-softwaresuite).

\section{Western blotting}

Western blot assays were performed using entire hippocampal tissue homogenates from control and $\mathrm{IH}$ exposed mice. Hippocampal tissue from animals exposed to $\mathrm{IH}$ was harvested for Western blot analysis $\sim 12-16 \mathrm{~h}$ following the end of the $\mathrm{IH}_{10}$ protocol.

For quantitative analysis of HIF1a (R\&D Systems catalog \#AF1935, RRID:AB_355064) and proliferating cell nuclear antigen (PCNA; Bethyl catalog \#A300-276A, RRID: AB_263393) content. Stepwise separation of cytoplasmic and nuclear protein extracts was prepared by NE-PER nuclear and cytoplasmic extraction kit (Thermo Scientific, 78833) by following manufacturer instructions. Briefly, cytoplasmic fragment was obtained by homogenizing tissue using a tissue grinder and then by pipetting in cytoplasmic extraction buffers. After isolation of cytoplasmic fragment, the insoluble pellet that contains nuclear proteins was suspended in nuclear extraction buffer and separated by centrifugation. Halt Protease Inhibitor (Thermo Scientific, 1860932) was added into cytoplasmic and nuclear extraction buffers to prevent protein degradation. Analyses for HIF1a and PCNA proteins were conducted by Raybiotech, using the automated capillary electrophoresis immunoassay machine (WES, ProteinSimple). The samples, blocking reagent, wash buffer, primary antibodies, secondary antibodies, and chemiluminescent substrate were dispensed into designated wells in the manufacturer provided microplate. After plate loading, the separation electrophoresis and immunodetection steps took place in the capillary system and were fully automated. Auto Western blot analysis was 
conducted at room temperature, and instrument default settings were used.

Quantitative Western blot analysis for GluN1, PSD-95, NADPH oxidase 4 (NOX4), and GAPDH were performed from hippocampal homogenates homogenized using either M-PER TM (Thermo Fisher Scientific) or RIPA buffer (Thermo Fisher Scientific) in the presence of protease and phosphatase inhibitors (Thermo Fisher Scientific) in cold ice. Samples were centrifuged at $14 \mathrm{rpm}$ for $15 \mathrm{~min}$ at $4^{\circ} \mathrm{C}$ and the pellet was discarded. Samples were boiled for $15 \mathrm{~min}$ in loading buffer (Bio-Rad) at $60^{\circ} \mathrm{C}$ before loading 20- to $25-\mu \mathrm{g}$ protein onto $4-20 \%$ Mini-PROTEAN TGX Stain-Free TM Protein Gels (Bio-Rad) and electrophoresed (120 V for $100 \mathrm{~min}$ ) using Tris/glycine/SDS buffer (Bio-Rad). Gels were transferred to PVDF membrane (Bio-Rad) using Transfer-Blot Turbo System (Bio-Rad). Membranes were subsequently blocked $(1 \mathrm{~h}$, room temperature) with $5 \%$ non-fat milk (Bio-Rad) or $5 \%$ bovine serum albumin (BSA; Sigma-Aldrich) in Tris-buffered saline (BioRad). Membranes were incubated (at $4^{\circ} \mathrm{C}$ overnight in $5 \%$ non-fat milk or BSA) under constant shaking with primary antibodies: monoclonal rabbit anti GluN1 (1:2000, Abcam), monoclonal rabbit anti-PSD-95 (1:1000, Cell signal), monoclonal rabbit anti- NOX4 (1:2000, Abcam), or monoclonal mouse anti-GAPDH (1:5000, Jackson ImmunoResearch). After washing three times with Tris-buffered saline-Tween $0.2 \%$ for $15 \mathrm{~min}$, membranes were incubated $(1 \mathrm{~h}$, room temperature) with the appropriate secondary antibodies. Finally, membranes were washed three times with Tris-buffered saline-Tween $0.2 \%$ for $15 \mathrm{~min}$, and immunoreactive proteins were detected with enhanced chemiluminescence $(\mathrm{ECL})$ reagents according to manufacturer instructions (BioRad). Signals were captured with the ChemiDoc system (Bio-Rad). The ImageJ image program (National Institutes of Health) was used to quantify optical band intensity.

\section{Protein carbonyls}

Whole-cell protein lysates were isolated from hippocampal tissues by using M-PER mammalian protein extraction reagent (Thermo Scientific, 78501) and by adding Halt Protease Inhibitor (Thermo Scientific, 1860932). Protein lysates were immediately processed or kept in $-80^{\circ} \mathrm{C}$ until used. The amount of protein carbonyls was determined using a Protein Carbonyl Colorimetric Assay kit (Cayman Chemical, catalog \#10005020), per manufacturer instructions and absorbance was measured at a wavelength between $360-385 \mathrm{~nm}$ using a plate reader. Protein content was determined using a Protein Determination kit (Cayman Chemical, catalog \#704002).

\section{Experimental design and statistical analyses}

All $n$ values are total number of animals, unless otherwise noted. Statistics were performed using Origin 8 Pro (OriginLab, RRID:SCR_014212) or Prism 6 (GraphPad Software; RRID:SCR_015807). Comparisons between two groups were conducted using unpaired two-tailed $t$ tests with Welch's correction. To compare three or more groups, a one-way ANOVA was performed followed by post hoc Dunnett's test comparing experimental groups to control. Results are presented as single data points from each individual experiment and/or as the mean \pm SEM. Significance was considered when $p<0.05$. See Table 1 for statistical information related to analyses presented in this study.

\section{Results}

HIF1a protein content was measured in nuclear extracts prepared from wild-type mice unexposed to $\mathrm{IH}$ (control) and exposed to $10 \mathrm{~d}$ of $\mathrm{IH}\left(\mathrm{IH}_{10}\right)$. Nuclear HIF1a was approximately two times greater in extracts from $\mathrm{IH}_{10}$ than control (control $n=4, \mathrm{IH}_{10} n=4$; Fig. 1A). To determine the behavioral consequences of $\mathrm{IH}$, we examined spatial learning and memory by assessing performance in a Barnes maze in control $(n=11)$ and $\mathrm{IH}_{10}$ $(n=10)$. During training, control and $\mathrm{IH}_{10}$ exhibited progressive improvement on locating the exit zone as indicated by the decrease in latency to exit over course of three training sessions and was similar between groups (Fig. 1B).

In the probe trial (when the exit was closed), no difference was evident between the total distance traveled between control and $\mathrm{IH}_{10}$ (control: $25.22 \pm 1.74 \mathrm{~m}$ vs $\mathrm{IH}_{10}$ : $27.91 \pm 2.21 \mathrm{~m}, p=0.35$; data not shown) suggesting no locomotor differences between groups. However, performance in locating the exit zone was different between control and $\mathrm{IH}_{10}$ as the distance to initial entry to the exit zone was greater in $\mathrm{IH}_{10}$ (control: $2.60 \pm 0.70 \mathrm{~m}$ vs $\mathrm{IH}_{10}$ : $10.34 \pm 3.32 \mathrm{~m}, p=0.048$; Fig. $1 C$ ), and a larger latency to initial entry exit zone was observed in $\mathrm{IH}_{10}$ (control: $22.60 \pm 6.28 \mathrm{~s}$ vs $\mathrm{IH}_{10}: 117.90 \pm 37.47 \mathrm{~s}, p=0.034$; Fig. $1 C)$. Additionally, when comparing the probability to exit zone entry, the control group consistently discriminated the location of exit hole against the other holes, yet this was not apparent in $\mathrm{IH}_{10}$ (control: $15.93 \pm 2.39 \%$ vs $\mathrm{IH}_{10}$ : $6.44 \pm 1.38 \%, p=0.0037$; Fig. 1D). Together, these findings indicated that wild-type animals exposed to $\mathrm{IH}$ have increased expression of HIF1a and impairments to spatial memory.

Nuclear HIF1a protein content was similar between extracts from hippocampi of $\mathrm{HIF}_{1} \mathrm{a}^{+/-}$mice unexposed to $\mathrm{IH}\left(0-\mathrm{HIF}_{1} \mathrm{a}^{+/-}\right)$when compared with $\mathrm{HIF}^{+/-} \mathrm{a}^{+/}$mice exposed to $10 \mathrm{~d}$ of $\mathrm{IH}\left(10-\mathrm{HIF}_{1} \mathrm{a}^{+/-} ; 0-\mathrm{HIF}_{1} \mathrm{a}^{+/-}, n=4,10-\right.$ $\mathrm{HIF}^{+/-} n=4$; Fig. 1E). In $0-\mathrm{HIF}^{+1 a^{+/-}}(n=7)$, and 10$\mathrm{HIF}_{1} \mathrm{a}^{+/-}(n=8)$ performance in the Barnes maze was similar over the course of the training sessions (Fig. 1F). During the probe trial, the total distance traveled by 0 $\mathrm{HIF}_{1} \mathrm{a}^{+/-}$to $10-\mathrm{HIF}_{\mathrm{a}}{ }^{+/-}$were similar $\left(0-\mathrm{HIF} \mathrm{a}^{+/-}=\right.$ $19.47 \pm 1.61 \mathrm{~m}, 10-\mathrm{HIF} \mathrm{a}^{+/-}=22.42 \pm 1.61 \mathrm{~m} ; p=0.55$; data not shown) suggesting no locomotor differences between groups. Moreover, the distance to initial entry to the exit zone $\left(0-\mathrm{HIF}_{1}{ }^{+/-}=2.37 \pm 0.91 \mathrm{~m}, 10-\mathrm{HIF}^{+/-} \mathrm{a}^{+/}=\right.$ $1.71 \pm 0.50 \mathrm{~m} ; p=0.54$; Fig. $1 \mathrm{G})$, latency to initial entry into the exit zone $\left(0-\mathrm{HIF} 1 \mathrm{a}^{+/-}=35.18 \pm 12.28 \mathrm{~s}, 10-\mathrm{HIF}^{+a^{+/-}}=\right.$ $57.28 \pm 27.08 \mathrm{~s} ; p=0.48$; Fig. $1 G)$; and the entry probability into the exit zone $\left(0-\mathrm{HIF}_{1}{ }^{++-}=8.75 \pm 1.38 \%\right.$, 10 $\mathrm{HIF} \mathrm{a}^{+/-}=15.51 \pm 4.73 \% ; p=0.21$; Fig. $1 H$ ) for $0-\mathrm{HIF} \mathrm{a}^{+/-}$ and $10-\mathrm{HIF} \mathrm{a}^{+/-}$were similar between both groups. These data demonstrate that in $\mathrm{HIF}_{1} \mathrm{a}^{+/-}$mice the $\mathrm{IH}$-dependent increase in nuclear HIF1a protein was mitigated, and spatial 
Table 1: Description of statistical tests and associated values used throughout the study

\begin{tabular}{|c|c|c|}
\hline Figure & Statistical test & Statistical values \\
\hline $1 A$ & Unpaired $t$ test with Welch's correction & $p=0.03 ; t=2.789, \mathrm{df}=3$ \\
\hline $1 B$, left & $\begin{array}{l}\text { One-way ANOVA, Dunnett's multiple com- } \\
\text { parison test }\end{array}$ & $\begin{array}{l}\text { One-way ANOVA } p=0.0044, F=7.191,1 \text { vs } 2 \text { (training session): } p<0.05, \mathrm{Cl} \text { of diff }=23.74- \\
217.9 ; 1 \text { vs } 3 \text { (training session): } p<0.01, \mathrm{Cl} \text { of diff }=47.11-241.3\end{array}$ \\
\hline $1 B$, right & $\begin{array}{l}\text { One-way ANOVA, Dunnett's multiple com- } \\
\text { parison test. }\end{array}$ & $\begin{array}{l}\text { One-way ANOVA } p=0.0006, F=11.68,1 \text { vs } 2 \text { (training session): } p<0.01, \mathrm{Cl} \text { of diff }=63.81- \\
239.3 ; 1 \text { vs } 3 \text { (training session): } p<0.001, \mathrm{Cl} \text { of diff }=66.88-242.3\end{array}$ \\
\hline $1 C$, left & Unpaired $t$ test with Welch's correction & $p=0.04, t=2.85, \mathrm{df}=9$ \\
\hline $1 C$, right & Unpaired $t$ test with Welch's correction & $p=0.03, t=2.501, \mathrm{df}=9$ \\
\hline $1 D$ & Unpaired $t$ test with Welch's correction & $p=0.0037 ; t=3.436, \mathrm{df}=15$ \\
\hline $1 E$ & Unpaired $t$ test with Welch's correction & $p=0.84 ; t=0.2118, \mathrm{df}=5$ \\
\hline $1 F$, left & $\begin{array}{l}\text { One-way ANOVA, Dunnett's multiple com- } \\
\text { parison test }\end{array}$ & $\begin{array}{l}\text { One-way ANOVA } p=0.0136, F=6.288,1 \text { vs } 2 \text { (training session): } p>0.05, \mathrm{Cl} \text { of diff }= \\
-12.74 \text { to } 207.3 ; 1 \text { vs } 3 \text { (training session): } p<0.01, \mathrm{Cl} \text { of diff }=44.13-264.2\end{array}$ \\
\hline $1 F$, right & $\begin{array}{l}\text { One-way ANOVA, Dunnett's multiple com- } \\
\text { parison test }\end{array}$ & $\begin{array}{l}\text { One-way ANOVA } p=0.0156, F=5.688,1 \text { vs } 2 \text { (training session): } p>0.05, \mathrm{Cl} \text { of diff }= \\
-3.202 \text { to } 221.3 ; 1 \text { vs } 3 \text { (training session): } p<0.05, \mathrm{Cl} \text { of diff }=36.56-261.1\end{array}$ \\
\hline $1 G$, left & Unpaired $t$ test with Welch's correction & $p=0.547, t=0.6258, \mathrm{df}=9$ \\
\hline $1 G$, right & Unpaired $t$ test with Welch's correction & $p=0.48, t=0.7431, \mathrm{df}=9$ \\
\hline $1 H$, left & Unpaired $t$ test with Welch's correction & $p=0.2120, t=1.356, \mathrm{df}=8$ \\
\hline $2 A$ & $\begin{array}{l}\text { One-way ANOVA, Dunnett's multiple com- } \\
\text { parison test }\end{array}$ & $\begin{array}{l}\text { One-way ANOVA } p=0.0004, F=10.20 \text {; control vs AP5: } p<0.01, \mathrm{Cl} \text { of diff }=21.28-62.13 \text {; con- } \\
\text { trol vs } 10-\mathrm{IH}: p<0.01, \mathrm{Cl} \text { of diff }=5.21-44.71 \text {; control vs } 10-\mathrm{IH}+\mathrm{AP} 5: p<0.01, \mathrm{Cl} \text { of diff }= \\
11.04-51.89\end{array}$ \\
\hline $2 B$ & $\begin{array}{l}\text { One-way ANOVA, Dunnett's multiple com- } \\
\text { parison test }\end{array}$ & $\begin{array}{l}\text { One-way ANOVA } p<0.0001, F=116.9 \text {; control vs AP5: } p<0.01, \mathrm{Cl} \text { of diff }=54.80-80.72 \text {; con- } \\
\text { trol vs } 10-\mathrm{IH}: p<0.01, \mathrm{Cl} \text { of diff }=56.41-82.32\end{array}$ \\
\hline $2 C$ & Unpaired $t$ test with Welch's correction & $p=0.94 ; t=0.065, \mathrm{df}=13.14$ \\
\hline $2 D$ & $\begin{array}{l}\text { One-way ANOVA, Dunnett's multiple com- } \\
\text { parison test }\end{array}$ & $\begin{array}{l}\text { One-way ANOVA } p<0.0001, F=54.50 ; 0-\mathrm{HIF} 1 \mathrm{a}+/- \text { vs } 10-\mathrm{HIF} 1 \mathrm{a}+/-: p>0.05, \mathrm{Cl} \text { of diff }=- \\
20.49 \text { to } 10.15 ; 10-\mathrm{HIF} 1 \mathrm{a}+/- \text { vs } 10-\mathrm{HIF} 1 \mathrm{a}+/-+\mathrm{AP} 5: p<0.01, \mathrm{Cl} \text { of } \text { diff }=42.75-75.42\end{array}$ \\
\hline $3 B$, top & $\begin{array}{l}\text { One-way ANOVA, Dunnett's multiple com- } \\
\text { parison test }\end{array}$ & $\begin{array}{l}\text { One-way ANOVA } p=0.56, F=0.70 \text {; control vs } \mathrm{IH}_{10}: p>0.05, \mathrm{Cl} \text { of diff }=-24.53 \text { to } 54.60 \text {; con- } \\
\text { trol vs } 0-\mathrm{HIF} 1 \mathrm{a}+/-: p>0.05, \mathrm{Cl} \text { of diff }=-20.36 \text { to } 54.60 \text {; control vs } 10-\mathrm{HIF} 1 \mathrm{a}+/- \text { : } \\
p>0.05, \mathrm{Cl} \text { of diff }=-33.12 \text { to } 39.06\end{array}$ \\
\hline $3 B$, bottom & $\begin{array}{l}\text { One-way ANOVA, Dunnett's multiple com- } \\
\text { parison test }\end{array}$ & $\begin{array}{l}\text { One-way ANOVA } p=0.56, F=0.70 \text {; control vs } \mathrm{IH}_{10}: p<0.05, \mathrm{Cl} \text { of diff }=-70.53 \text { to }-6.241 \text {; con- } \\
\text { trol vs } 0 \text { - } \mathrm{HIF} 1 \mathrm{a}+/-: p>0.05, \mathrm{Cl} \text { of diff }=-56.75 \text { to } 3.840 \text {; control vs } 10-\mathrm{HIF} 1 \mathrm{a}+/- \text { : } \\
p>0.05, \mathrm{Cl} \text { of diff }=-40.38 \text { to } 17.97\end{array}$ \\
\hline $3 C$ & $\begin{array}{l}\text { One-way ANOVA, Dunnett's multiple com- } \\
\text { parison test }\end{array}$ & $\begin{array}{l}\text { One-way ANOVA } p=0.014, F=4.74 ; \text { control vs } \mathrm{IH}_{10}: p<0.05, \mathrm{Cl} \text { of diff }=0.96-0.78 ; \text { control } \\
\text { vs } 0-\mathrm{HIF} 1 \mathrm{a}+/-: p>0.05, \mathrm{Cl} \text { of diff }=-0.38 \text { to } 0.05 ; \text { control vs } 10-\mathrm{HIF} 1 \mathrm{a}+/-: p>0.05, \mathrm{Cl} \text { of } \\
\text { diff }=-0.27 \text { to } 0.157\end{array}$ \\
\hline $3 D$ & $\begin{array}{l}\text { One-way ANOVA, Dunnett's multiple com- } \\
\text { parison test }\end{array}$ & $\begin{array}{l}\text { One-way ANOVA } p=0.14, F=2.39 \text {; control vs } \mathrm{IH}_{10}: p>0.05, \mathrm{Cl} \text { of diff }=-0.42 \text { to } 0.27 ; \text { control } \\
\text { vs } 0-\mathrm{HIF} 1 \mathrm{a}+\mathrm{I}-: p>0.05, \mathrm{Cl} \text { of diff }=-0.63 \text { to } 0.0636 \text {; control vs } 10-\mathrm{HIF} 1 \mathrm{a}+\mathrm{I}-: p>0.05, \mathrm{Cl} \\
\text { of diff }=-0.35 \text { to } 0.33\end{array}$ \\
\hline $4 A$ & $\begin{array}{l}\text { One-way ANOVA, Dunnett's multiple com- } \\
\text { parison test }\end{array}$ & $\begin{array}{l}\text { One-way ANOVA } p=0.006 F=6.871 \text {, control vs } \mathrm{IH}_{10}: p<0.01 \mathrm{Cl} \text { of diff }=-105.1 \text { to }-17.65 \\
\text { control vs } 0-\mathrm{HIF} 1 \mathrm{a}+/-: p>0.05 \mathrm{Cl} \text { of diff }=-52.12 \text { to } 35.32 ; \text { control vs } 10-\mathrm{HIF} 1 \mathrm{a}+/-: p> \\
0.05 \mathrm{Cl} \text { of diff }=-40.58 \text { to } 46.85\end{array}$ \\
\hline $4 B$ & $\begin{array}{l}\text { One-way ANOVA, Dunnett's multiple com- } \\
\text { parison test }\end{array}$ & $\begin{array}{l}\text { One-way ANOVA } p=0.003, F=11.70 \text {; control vs } \mathrm{IH}_{10}: p>0.05, \mathrm{Cl} \text { of diff }=-1.85 \text { to }-0.28 \text {; con- } \\
\text { trol vs } 0-\mathrm{HIF} 1 \mathrm{a}+/-: p>0.05, \mathrm{Cl} \text { of diff }=-0.35 \text { to } 0.45 ; \text { control vs } 10-\mathrm{HIF} 1 \mathrm{a}+/-: p>0.05, \mathrm{Cl} \\
\text { of diff }=-0.28 \text { to } 0.52\end{array}$ \\
\hline $5 A$ & $\begin{array}{l}\text { One-way ANOVA, Dunnett's multiple com- } \\
\text { parison test }\end{array}$ & $\begin{array}{l}\text { One-way ANOVA } p=0.0023, F=10.00 \text {; control vs } \mathrm{IH}_{10}: p<0.01, \mathrm{Cl} \text { of diff }=0.09-0.75 \text {; control } \\
\text { vs } 10-\mathrm{MnTMPyP}: p>0.05, \mathrm{Cl} \text { of diff }=-0.49 \text { to } 0.26\end{array}$ \\
\hline $5 B$ & $\begin{array}{l}\text { One-way ANOVA, Dunnett's multiple com- } \\
\text { parison test }\end{array}$ & $\begin{array}{l}\text { One-way ANOVA } p<0.0001, F=57.60 \text {, control vs } \mathrm{IH}: p<0.001, \mathrm{Cl} \text { of diff }=50.58-88.15 \text {; con- } \\
\text { trol vs } \mathrm{IH}+\text { MnTMPyP: } p>0.05, \mathrm{Cl} \text { of diff }=-19.59 \text { to } 17.98\end{array}$ \\
\hline $5 C$, top & $\begin{array}{l}\text { One-way ANOVA, Dunnett's multiple com- } \\
\text { parison test }\end{array}$ & $\begin{array}{l}\text { One-way ANOVA } p=0.0008, F=6.32,1 \text { vs } 2 \text { (training session): } p>0.05, \mathrm{Cl} \text { of diff }= \\
-40.99 \text { to } 139.5 ; 1 \text { vs } 3 \text { (training session): } p<0.001, \mathrm{Cl} \text { of diff }=71.59-252.1\end{array}$ \\
\hline $5 C$, bottom & $\begin{array}{l}\text { One-way ANOVA, Dunnett's multiple com- } \\
\text { parison test }\end{array}$ & $\begin{array}{l}\text { One-way ANOVA } p=0.0056, F=9.10,1 \text { vs } 2 \text { (training session): } p>0.05, \mathrm{Cl} \text { of diff }= \\
\quad-25.40 \text { to } 187.3 ; 1 \text { vs } 3 \text { (training session): } p<0.01, \mathrm{Cl} \text { of diff }=55.75-268.4\end{array}$ \\
\hline $5 D$ & Unpaired $t$ test with Welch's correction & $p=0.0005 ; t=4.292, \mathrm{df}=16.7112$ \\
\hline
\end{tabular}

memory was unaffected by $\mathrm{IH}$. Furthermore, these data raise the possibility that increased hippocampal nuclear HIF1a signaling causes deficits to hippocampal LTP.

The mechanisms underlying LTP are key substrates for learning and memory. We, therefore, examined LTP from area CA1 in hippocampal in brain slices from control and $\mathrm{IH}_{10}$. LTP from control was consistently evoked by HFS

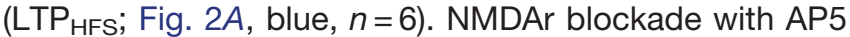
attenuated LTP $_{\mathrm{HFS}}$ magnitude but did not prevent the occurrence of the phenomenon (Fig. $2 A$, green, $n=5$ ). These findings demonstrated that both NMDAr-dependent and NMDAr-independent mechanisms contributed to

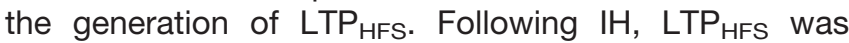
smaller in magnitude (Fig. $2 A$, red, $n=6$ ) and was no longer sensitive to AP5 (Fig. 2A, gold, $n=5$ ).

We next examined whether IH prevented another LTP

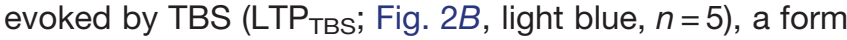
of synaptic potentiation dependent on the NMDAr, as 
A

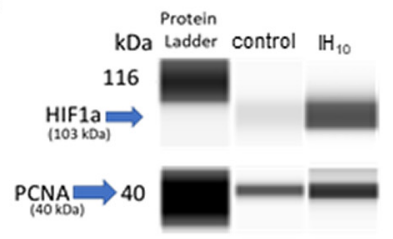

B

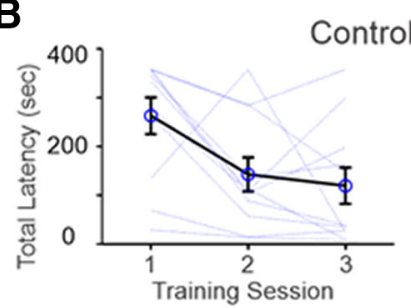

C
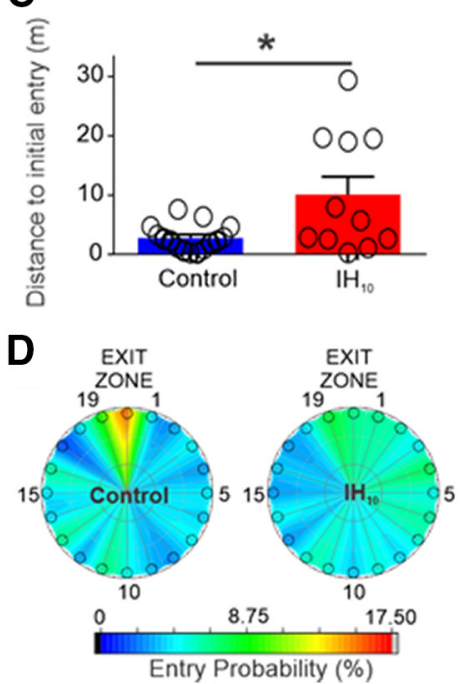
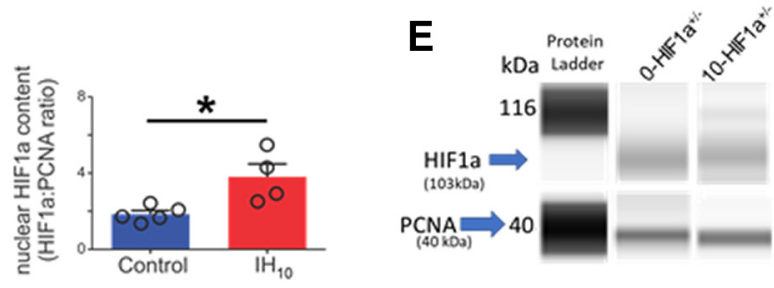

$\mathbf{F}$

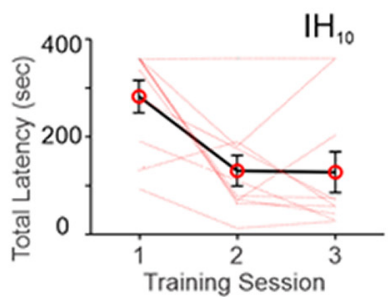

$\mathbf{F}$
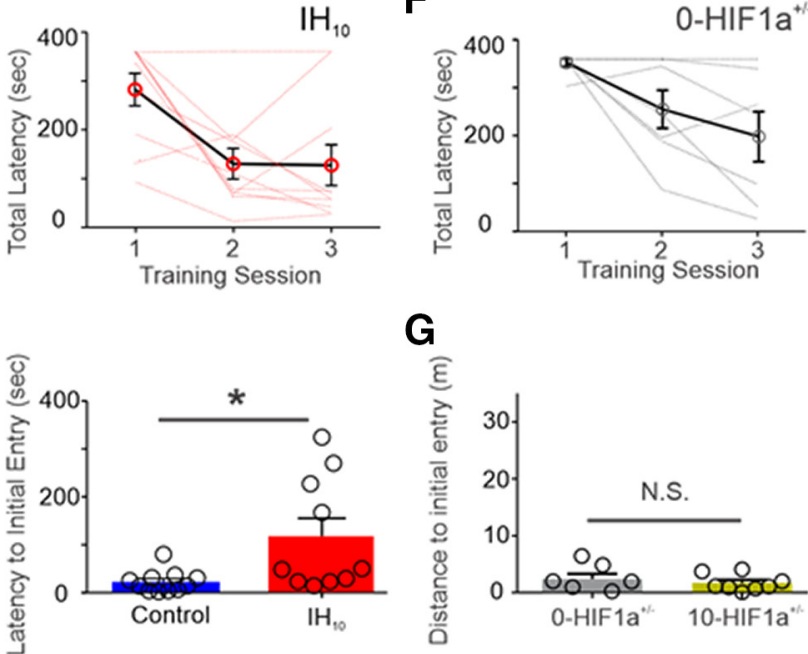

G
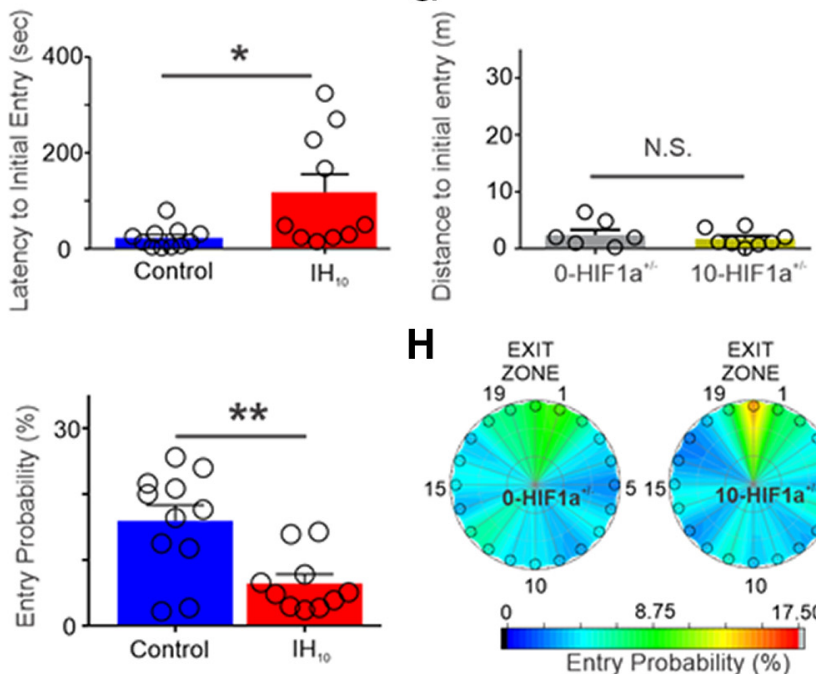

H

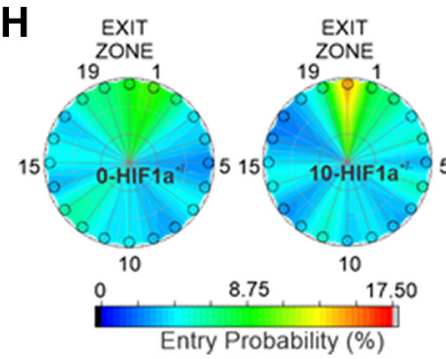

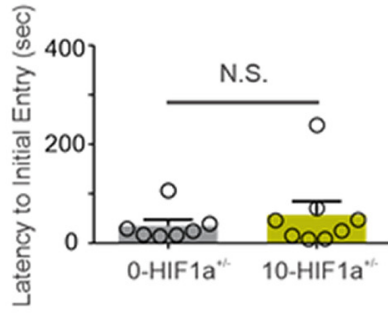
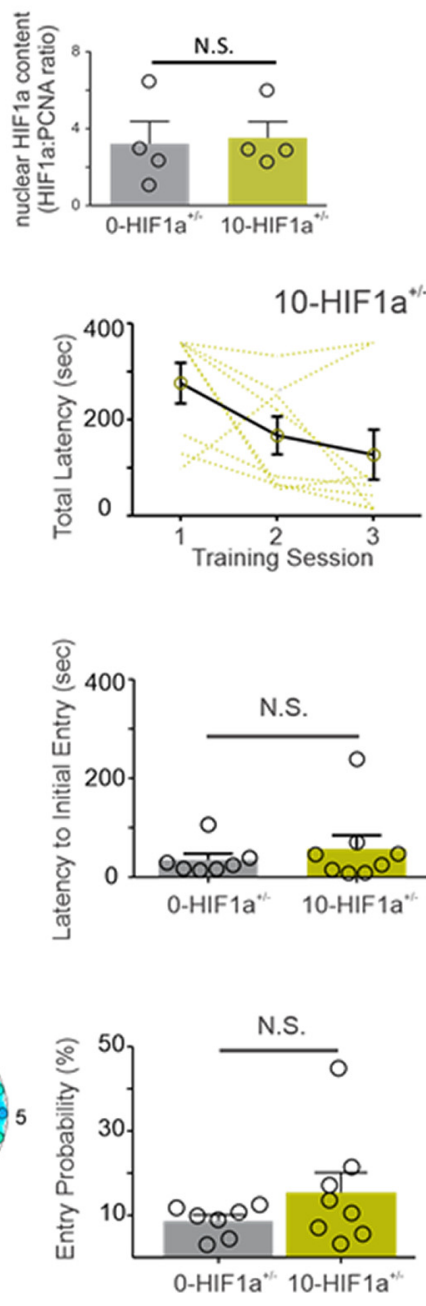

Figure 1. Ten days of $\mathrm{IH}$ increases hippocampal HIF1a and disrupts Barnes maze performance in wild-type mice but not in HIF1a+/-. A, left, Representative digitized Western blotting images for HIF1a (103 kDa) and PCNA (40 kDa) in hippocampal nuclear protein fractions from control $(n=4)$ and $\mathrm{IH}_{10}(n=4)$. Right, Quantification of HIF1a protein normalized to PCNA revealed that nuclear HIF1a was increased in $\mathrm{IH}_{10}$ when compared with control $(p=0.019)$. $\boldsymbol{B}$, Total latency to exit the Barnes maze during three training sessions in control $(n=10)$ and in $\mathrm{IH}_{10}(n=11)$. Each blue (control) and red $\left(\mathrm{IH}_{10}\right)$ line represents an individual performance during training. Training to the exit was conducted over three sessions. Each session was separated by 24 hours. $\boldsymbol{C}$, Left, During the probe trial, the distance traveled to initially enter the exit zone was shorter in control when compared with $\mathrm{IH}_{10}(p=0.048)$. Right, Latency to initial entry was smaller in control as well $(p=0.034)$. $\boldsymbol{D}$. Heat maps of the mean entry probability across all false exits $(1-19)$ and the exit zone during probe trial for the control and $\mathrm{IH}_{10}$. Comparison of entry probability into the exit zone during the probe trial reveals that control has a greater probability for entering the exit zone when compared with $\mathrm{IH}_{10}(p=0.004)$. $\boldsymbol{E}$, Left, Representative digitized Western blotting images HIF1a and PCNA in hippocampal nuclear protein fractions from $0-\mathrm{HIF}^{+/-}(n=4)$ and $10-$ $\mathrm{HIF} \mathrm{a}^{+/-}(n=4)$. Right, Quantification of HIF1a protein normalized to PCNA revealed that nuclear HIF1a is similar between 0$\mathrm{HIF}_{1} \mathrm{a}^{+/-}$and $10-\mathrm{HIF}_{1} \mathrm{a}^{+/-}(p=0.84) . \boldsymbol{F}$, Total latency to exit the Barnes maze during three training sessions in $0-\mathrm{HIF} 1 \mathrm{a}^{+/-}(n=7)$ and in $10-\mathrm{HIF}_{1} \mathrm{a}^{+/-}(n=8)$. Each gray $\left(0-\mathrm{HIF} \mathrm{a}^{+/-}\right)$and yellow $\left(10-\mathrm{HIF}^{+\mathrm{a}^{+/}}\right)$line represents an individual performance during training. All experimental groups exhibit decreased total latency over the course of training. G, Left, In HIF1a ${ }^{+/-}$, the distance initial to initial entry into the exit zone was similar between $0-\mathrm{HIF}_{1} \mathrm{a}^{+/-}$and $10-\mathrm{HIF}_{1} \mathrm{a}^{+/-}(p=0.55)$. Right, Latency to initial entry into the exit zone during the probe trial were similar between $0-\mathrm{HIF}_{1} \mathrm{a}^{+/-}$and $10-\mathrm{HIF} 1 \mathrm{a}^{+/-}(p=0.39)$. $\boldsymbol{H}$, Heat maps of the mean entry probability into all zones during the probe trial for $0-\mathrm{HIF}_{1} \mathrm{a}^{+/-}$and $10-\mathrm{HIF}_{1} \mathrm{a}^{+/-}$. Entry probability was similar between $0-\mathrm{HIF} 1 \mathrm{a}^{+/-}$and $10-$ $\mathrm{HIF}_{1} \mathrm{a}^{+/-}(p=0.21) ; * p<0.05 ; * * p<0.01$; N.S., $p>0.05$.

AP5 prevent $\mathrm{LTP}_{\mathrm{TBS}}$ (Fig. $2 B$, light green, $n=5$ ). Following IH, LTP ${ }_{\text {TBS }}$ could no longer be evoked (Fig. $2 B$, pink, $n=5$ ).

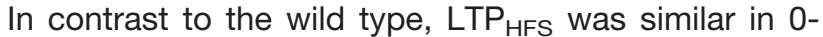
$\mathrm{HIF}_{1} \mathrm{a}^{+/-}$(Fig. 2C, gray $\left.n=8\right)$ and in $10-\mathrm{HIF}_{1} \mathrm{a}^{+/-}($Fig. $2 \mathrm{C}$, dark yellow, $n=8$ ). In the hippocampal brain slice, the magnitude of $\mathrm{LTP}_{\mathrm{TBS}}$ was similar between $0-\mathrm{HIF}_{\mathrm{F}} \mathrm{a}^{+/-}$ (Fig. $2 D$, light gray, $n=6$ ) and in $10-\mathrm{HIF}^{+/-}$(Fig. $2 D$, light yellow, $n=5$ ). Additionally, AP5 blocked LTP the $10-\mathrm{HIF}^{+/-}$(Fig. $2 D$, light green, $n=4$ ). Together, these findings suggested that $\mathrm{IH}$-dependent HIF1a 
A

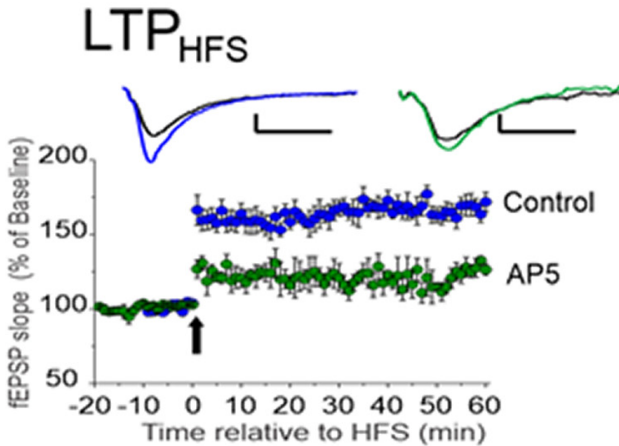

B

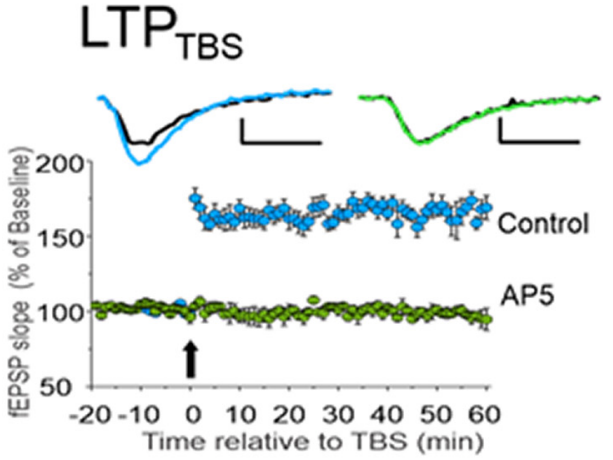

C
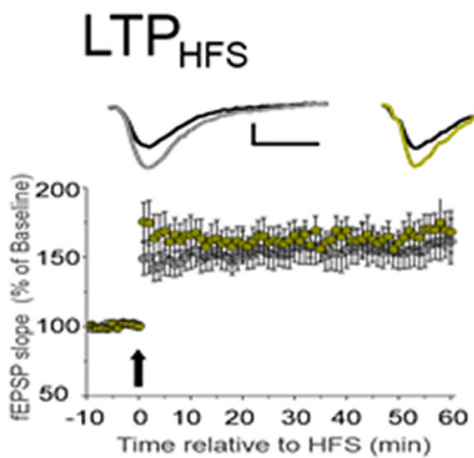

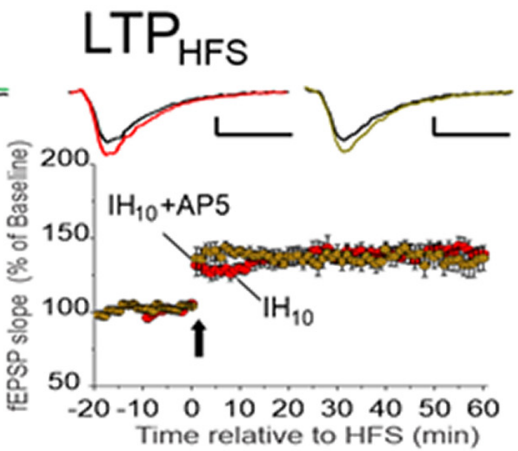

LTP $_{\text {TBS }}$

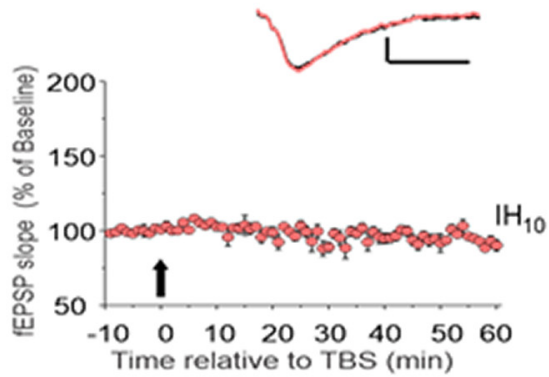

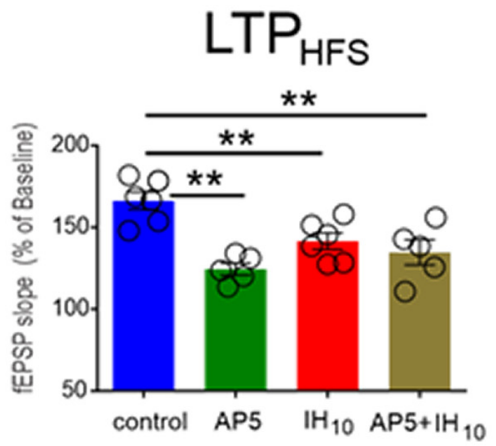

LTP $_{\text {TBS }}$

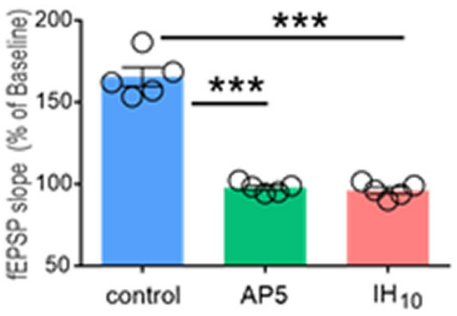

D $\quad$ LTP $_{\text {TBS }}$
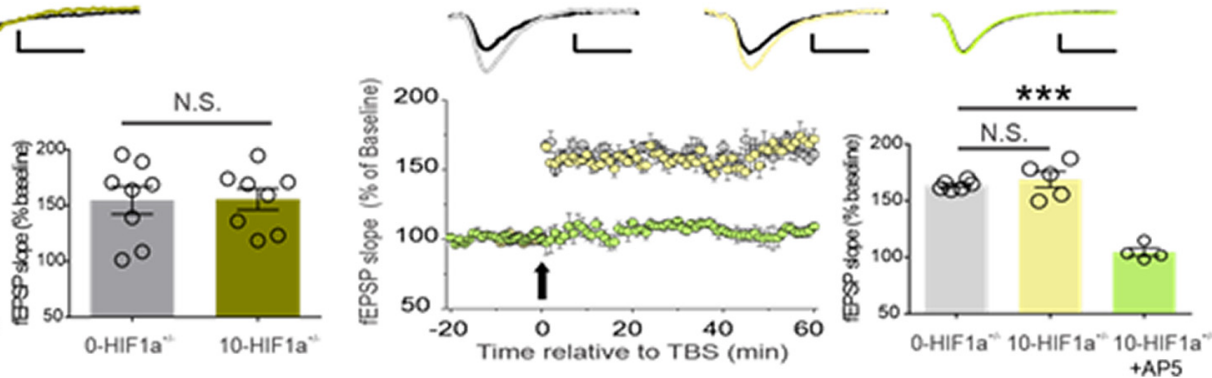

Figure 2. IH suppresses NMDAr-dependent synaptic potentiation in wild-type hippocampal slices, but NMDAr-dependent LTP is unaffected by $\mathrm{IH}$ in the hippocampal slices from HIF1a ${ }^{+/}$. $\boldsymbol{A}$, LTP was evoked using HFS in control (blue, $\left.n=6\right)$ is attenuated by

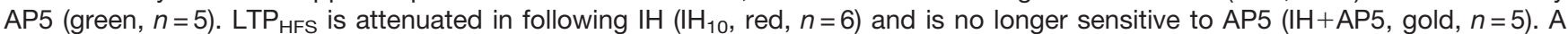

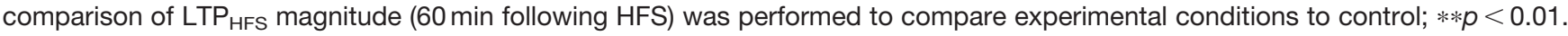
$\boldsymbol{B}, \mathrm{LTP}_{\mathrm{TBS}}$ is readily evoked in control (light blue, $n=5$ ) and is completely blocked by AP5 (light green, $n=5$ ). Following IH, LTP present $\left(\mathrm{IH}_{10}\right.$, pink, $\left.n=5\right)$. Following a one-way ANOVA, a post hoc comparison of $\mathrm{LTP}_{\mathrm{TBS}}$ magnitude $(60 \mathrm{~min}$ following TBS) was

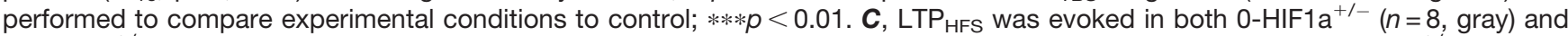
$10-\mathrm{HIF}_{1} \mathrm{a}^{+/-}\left(n=8\right.$, dark yellow). No difference was found when comparing LTP $\mathrm{HFs}_{\mathrm{magnitude}}$ between $0-\mathrm{HIF} 1 \mathrm{a}^{+/-}$and $10-$ $\mathrm{HIF}_{1} \mathrm{a}^{+/-}(p=0.94)$. $\boldsymbol{D}$, LTP $\mathrm{TBS}_{\mathrm{TB}}$ was evoked in both $0-\mathrm{HIF}_{1} \mathrm{a}^{+/-}\left(n=6\right.$, light gray), 10-HIF1a ${ }^{+/-}(n=5$, light yellow), and $10-$ $\mathrm{HIF}_{1} \mathrm{a}^{+/-}+\operatorname{AP5}\left(n=5\right.$, light green). No difference was found when comparing LTP $\mathrm{TBS}$ magnitude of $0-\mathrm{HIF}_{1} \mathrm{a}^{+/-}$and $10-\mathrm{HIF} 1 \mathrm{a}^{+/-}$. Representative traces illustrate baseline (black) and $60 \mathrm{~min}$ following HFS (colored trace). Scale bars: $0.2 \mathrm{mV} / 10 \mathrm{~ms}$. In experiments using AP5, electrophysiological recordings began at 20 min before eliciting LTP (i.e., $t=-20$ ) while AP5 was applied 10 before eliciting LTP (i.e., $t=-10$ ). For all the experiment, the arrow represents the electric protocols: HFS or TBS; $* * * p<0.001, * * p<0.01 ; N . S$., $p>0.05$.

signaling suppresses NMDAr-dependent potentiation by disrupting the NMDAr physiology. To test this, we examined the contribution of the NMDAr to the unpotentiated fEPSP.

A fEPSP with maximal amplitude in aCSF (fEPSP $\mathrm{Fax}_{\max }$ ) was evoked using saturating current stimulus $(700 \mu \mathrm{A}$; Fig. $3 \mathrm{~A}$, black, aCSF) in control $\left(n=6, \mathrm{fEPSP}_{\max }=-1.05 \pm 0.14 \mathrm{mV}\right)$, $\mathrm{IH}_{10}\left(n=7, \mathrm{fEPSP}_{\max }=-0.85 \pm 0.08 \mathrm{mV}\right), 0-\mathrm{HIF} \mathrm{a}^{+/-}(n=9$,
$\left.\mathrm{fEPSP}_{\text {max }}=-0.941 \pm 0.04 \mathrm{mV}\right)$, and $10-\mathrm{HIF} \mathrm{a}^{+/-}(n=11$, $\mathrm{fEPSP}_{\max }=-0.90 \pm 0.06 \mathrm{mV}$ ). When compared with control, no difference in $\mathrm{fEPSP}_{\max }$ was observed from any experimental group (one-way ANOVA: $p=0.39, F=1.035$; control vs $\mathrm{IH}_{10}: p>0.05,95 \% \mathrm{Cl}$ of diff $=-0.4960$ to $0.09,542$; control vs $0-\mathrm{HIF}^{+1 /-}: p>0.05,95 \% \mathrm{Cl}$ of diff $=-0.3938$ to $0.1665 ; 10-\mathrm{HIF} \mathrm{a}^{+/-}: p>0.05,95 \% \mathrm{Cl}$ of diff $=-0.4219$ to 
A
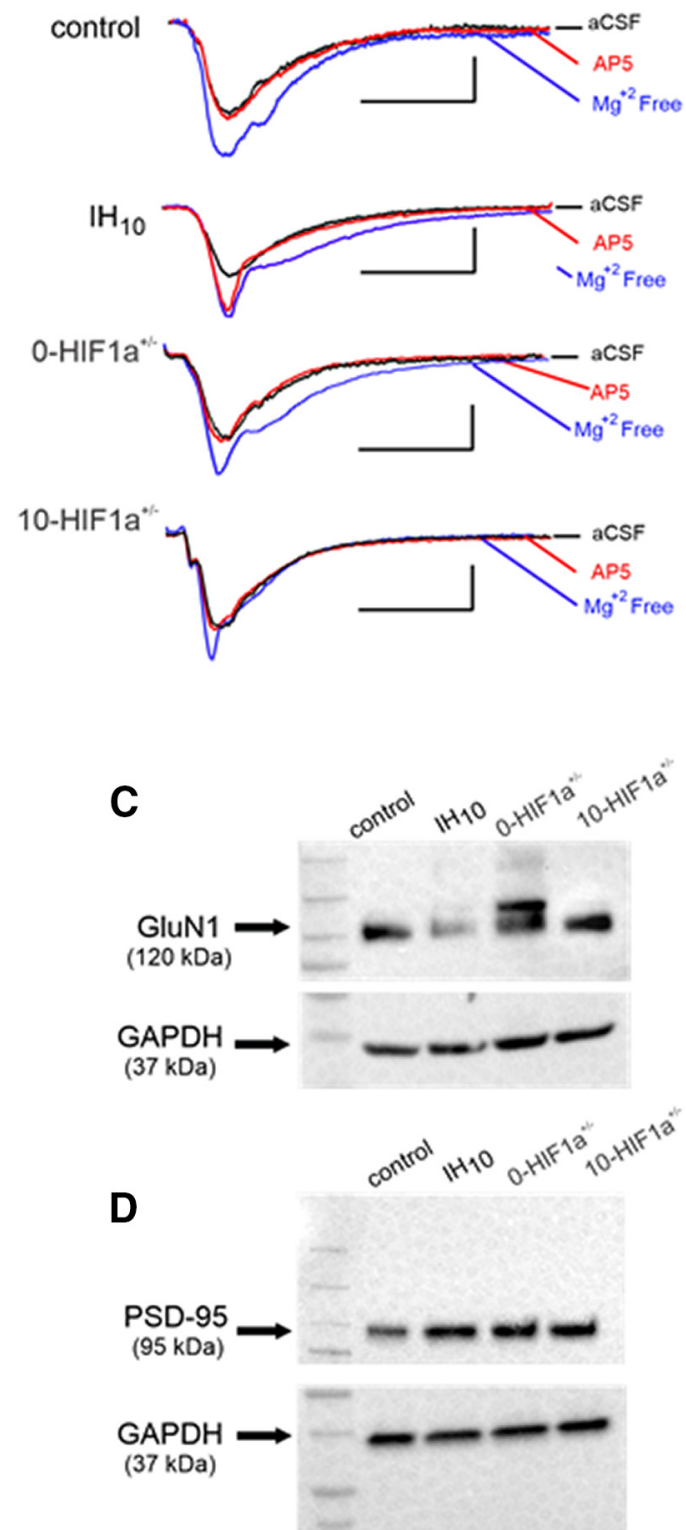

B
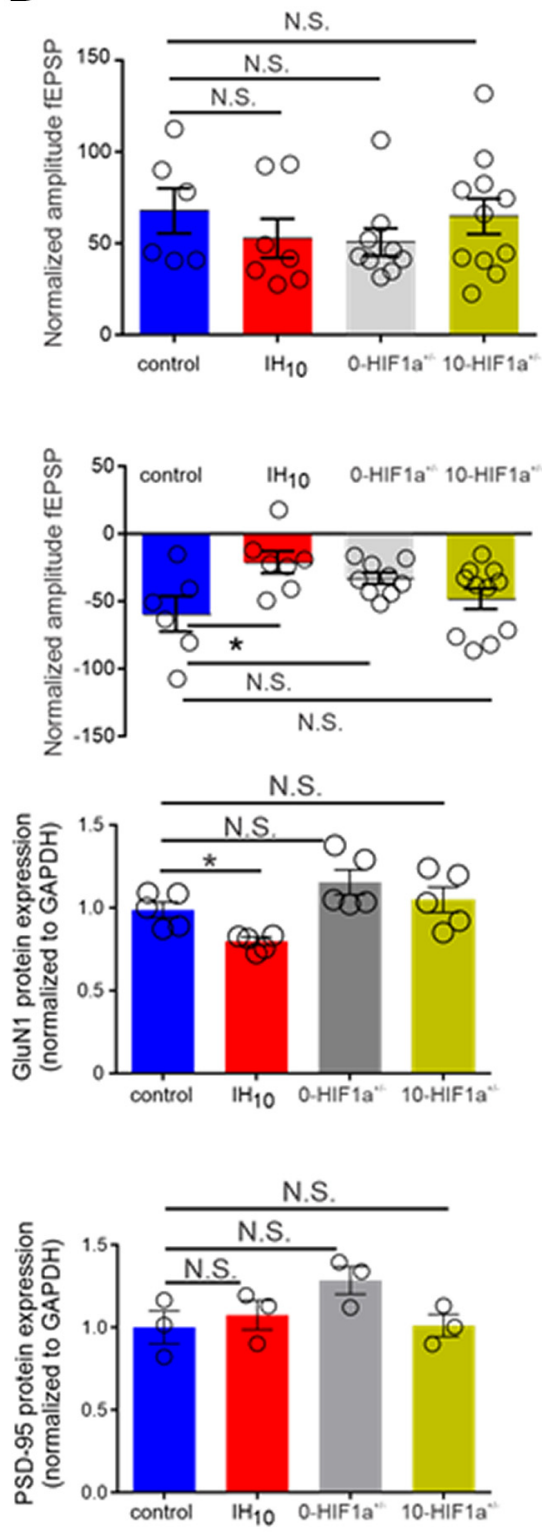

Figure 3. The IH reduces the contribution of the NMDAr to fEPSP and GluN1 protein from wild-type mice but does not induce these changes in $\mathrm{HIF}_{1} \mathrm{a}^{+/-}$. $\boldsymbol{A}$, Representative traces of the fEPSP from control, $\mathrm{IH}_{10}, 0-\mathrm{HIF}_{1} \mathrm{a}^{+/-}$, and $10-\mathrm{HIF} 1 \mathrm{a}^{+/-}$in: aCSF (black), $\mathrm{Mg}^{2+}$-free media (blue), and $\mathrm{Mg}^{2+}$-free media with AP5 (red). Scale bars: $0.4 \mathrm{mV} / 10 \mathrm{~ms}$. $\boldsymbol{B}$, top, Change in amplitude of the fEPSP from aCSF to $\mathrm{Mg}^{2+}$-free media. Bottom, Change in amplitude of the fEPSP from $\mathrm{Mg}^{2+}$-free media to $\mathrm{Mg}^{2+}$-free media with AP5; $* p<0.05$; N.S., $p>0.05$. C, left, Representative Western blottings of GluN1 and the housekeeping protein, GAPDH from control $(n=5), \mathrm{IH}_{10}(n=5), 0-\mathrm{HIF}_{1} \mathrm{a}^{+/-}(n=5)$, and 10-HIF1a ${ }^{+/-}(n=5)$. Right, Comparisons of normalized GluN1 protein expression were performed to compare experimental conditions to control. This revealed that $\mathrm{GluN1}_{1}$ was reduced in $\mathrm{IH}_{10}$ and unchanged in both 0 $\mathrm{HIF}_{1}{ }^{+/-}$and $10-\mathrm{HIF}^{+1}{ }^{+/-} ; * p<0.05$; N.S., $p>0.05$. $\boldsymbol{D}$, left, Representative Western blottings of PSD-95 and the housekeeping protein, GAPDH from control $(n=3), \mathrm{IH}_{10}(n=3), 0-\mathrm{HIF}_{\mathrm{a}} \mathrm{a}^{+/-}(n=3)$, and 10-HIF1a ${ }^{+/-}(n=3)$. Right, Comparisons of normalized PSD95 protein expression were performed to compare experimental conditions to control; $* p<0.05 ;$ N.S., $p>0.05$.

0.1176; data not shown). Switching to $\mathrm{Mg}^{2+}$-free aCSF relieved the $\mathrm{Mg}^{2+}$ blockade of existing NMDAr and caused the fEPSP to increase all groups (Fig. $3 A$, blue, $\mathrm{Mg}^{2+}$ free). The change in fEPSP amplitude from aCSF to $\mathrm{Mg}^{2+}$ free was not different when comparing the other experimental groups to control (Fig. 3B, top). However, the NMDAr antagonist, AP5, reduced the fEPSP in $0-\mathrm{HIF}_{1} \mathrm{a}^{+/-}$and $10-$ $\mathrm{HIF} \mathrm{a}^{+/-}$similar to that of control (Fig. $3 A$, red, AP5) yet was less effective in $\mathrm{IH}_{10}$ (Fig. $3 B$, bottom). These findings suggested that $\mathrm{IH}$ suppressed contribution of the conductance of NMDAr within neurons in a HIF1a dependent manner. Such an effect could be due to direct effects on unitary conductance of the NMDAr or by the down regulation of the receptor itself. Therefore, we examined whether expression of the GluN1, the obligatory subunit of the NMDAr, was disrupted by $\mathrm{IH}$. 
A

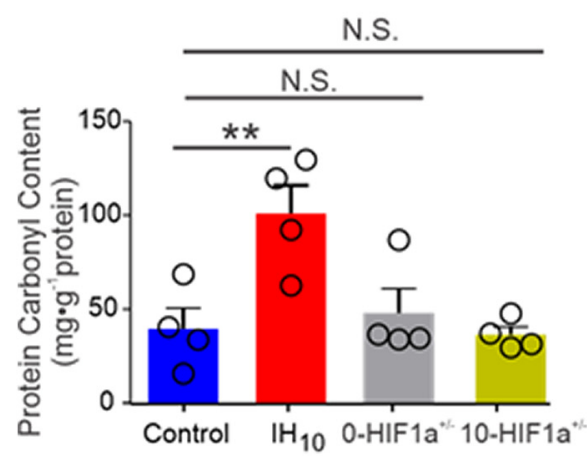

B
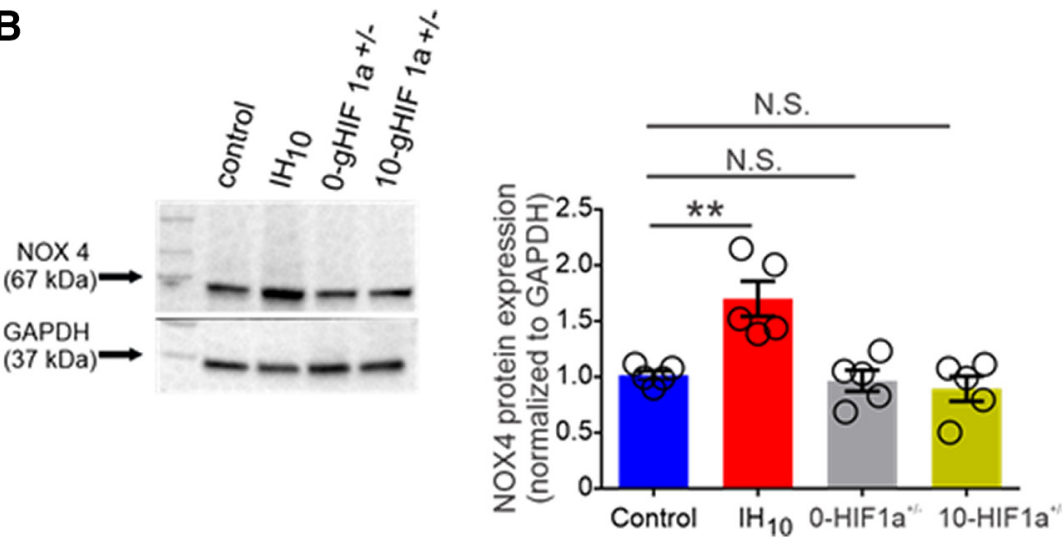

Figure 4. IH enhances protein carbonyl content and increase NOX4 expression in wild type but not in HIF1a ${ }^{+/-}$. $\boldsymbol{A}_{\text {, Hippocampal ho- }}$ mogenates from control $(n=4), \mathrm{IH}_{10}(n=4), 0-\mathrm{HIF}_{1} \mathrm{a}^{+/-}(n=4)$, and $10-\mathrm{HIF}^{+/-}(n=4)$. While $\mathrm{IH}_{10}$ displayed elevated protein, carbonyl content was not elevated in either $0-\mathrm{HIF}_{1} \mathrm{a}^{+/-}$or $10-\mathrm{HIF}_{1} \mathrm{a}^{+/-}$. $\boldsymbol{B}$, Comparison of the pro-oxidant enzyme, NOX4, from control $(n=5), \mathrm{IH}_{10}(n=5), 0-\mathrm{HIF}_{1} \mathrm{a}^{+/-}(n=5)$, and $10-\mathrm{HIF}^{+/-}(n=5)$ reveals that NOX4 is increased in $\left.\mathrm{IH}_{10} ; p<0.01\right)$, but not elevated in either $0-\mathrm{HIF}_{1} \mathrm{a}^{+/-}$or $10-\mathrm{HIF}_{1} \mathrm{a}^{+/-} ; * * p<0.01$; N.S., $p>0.05$.

We compared GluN1 subunit expression in control $(n=5), \mathrm{IH}_{10}(n=5), 0-\mathrm{HIF}_{\mathrm{a}}{ }^{+/-}(n=5)$, and $10-\mathrm{HIF} \mathrm{a}^{+/-}$ $(n=5)$. IH reduced GluN1 in wild-type hippocampi, yet GluN1 expression was similar to control in both 0 $\mathrm{HIF}_{1} \mathrm{a}^{+/-}$or $10-\mathrm{HIF} \mathrm{a}^{+/-}$(Fig. $3 \mathrm{C}$ ). This reduction in GluN1 may have resulted from an $\mathrm{IH}$-mediated reduction in synapse. Therefore, we sought to determine whether $\mathrm{IH}$ caused a reduction in a scaffolding protein of the glutamatergic synapse PSD-95 (Fig. $3 D, n=3$ per group). When compared with control, no difference in PSD-95 was detected any experimental group (Fig. 3D). These findings together indicated that IH-dependent HIF1a signaling specifically likely targets a reduction of the NMDAr by suppressing GluN1 expression without causing gross reductions in glutamatergic synapses. Such a reduction in NMDAr expression would likely contribute to the reduced sensitivity to AP5 following $\mathrm{IH}$ and contribute to impaired NMDAr-dependent LTP.

As IH-dependent HIF1a signaling can lead to a pro-oxidant condition, we next sought to determine whether $\mathrm{HH}$-dependent HIF1a signaling enhanced ROS production within the hippocampus. Protein carbonyl content in hippocampal homogenates from control $(n=4), \mathrm{IH}_{10}(n=4), 0-\mathrm{HIF}_{1} \mathrm{a}^{+/-}$ $(n=4)$, and $10-\mathrm{HIF1a}^{+/-}(n=4)$ revealed that protein carbonyl content was elevated in $\mathrm{IH}_{10}$ yet unchanged changed in homogenates from either $0-\mathrm{HIF}^{+/-}$or $10-\mathrm{HIF}^{+/-}$(Fig. $4 A$ ). NOX4 is a ROS generating protein that can be transcriptionally regulated by HIF1a (Diebold et al., 2010). Therefore, we next determined Nox4 expression in hippocampal homogenates from control $(n=5), \mathrm{IH}_{10}(n=5), 0-\mathrm{HIF}^{++-}(n=5)$, and $10-\mathrm{HIF}^{+/-}(n=5)$. NOX4 was elevated in $\mathrm{IH}_{10}$ yet unchanged changed in homogenates from either $0-\mathrm{HIF}{ }^{+/-}$or $10-\mathrm{HIF}^{+} \mathrm{a}^{+-}$(Fig. 4B). Together, these data suggest that enhanced ROS production by IH-dependent HIF1a signaling involves the upregulation of NOX4. However, $\mathrm{IH}$-dependent ROS production was involved with the changed expression of GluN1 remained uncertain.

To resolve the involvement of $\mathrm{IH}$-dependent ROS production on the regulation of GluN1, protein homogenates were prepared from four groups: control $(n=4)$; $\mathrm{IH}_{10}$
( $n=4)$; wild-type mice administered saline during $10 \mathrm{~d}$ of $\mathrm{IH}$ exposure $\left(\mathrm{IH}_{\text {Saline }}, n=4\right)$; wild-type mice administered the superoxide anion scavenger, MnTMPyP, during $\mathrm{IH}$ $\left(\mathrm{IH} \mathrm{MnTMPyP}_{\mathrm{P}}, n=4\right)$. GluN1 was reduced in $\mathrm{IH}_{10}$ and $\mathrm{IH}_{\text {Saline; }}$; however, GluN1 from 10-MnTMPyP was similar to that of control (Fig. $5 A$ ), which coincided with the ability to evoke $\operatorname{LTP}_{\text {TBS }}$ from $\mathrm{IH}_{\text {MnTMPyP }}(n=5$; Fig. $5 B)$. Behavioral performance was also assessed in $\mathrm{IH}_{\text {Saline }}(n=11)$ and $\mathrm{IH}_{\text {MnTMPyP }}(n=10)$. Both $\mathrm{IH}_{\text {Saline }}$ and $\mathrm{IH}_{\text {MnTMPyP }}$ exhibited a progressive improvement in locating the exit as indicated by the total latency to exit over the course of training (Fig. $5 C)$. During the probe trail, the two groups exhibited similar values for distance to initial entry into the exit zone $\left(\mathrm{IH}_{\text {Saline }}=0.29 \pm 0.06 \mathrm{~m}, \mathrm{IH}_{\text {MnTMPyP }}=0.28 \pm 0.05 \mathrm{~m}\right.$; $p=0.87$; data not shown), and similar latency to initial entry into the exit zone $\left(\mathrm{IH}_{\text {Saline }}=77.74 \pm 24.42 \mathrm{~s}\right.$, $\mathrm{IH}_{\text {MnTMPyP }}=26.00 \pm 5.67 \mathrm{~s} ; p=0.06$; data not shown), although the variance between the values for latency to initial entry was different between $\mathrm{IH}_{\text {Saline }}$ and $\mathrm{IH}_{\text {MnTMPyP }}$ $(F=17.00, \quad D F n=10, \quad \operatorname{Dfd}=11 ; p<0.0001 ;$ data not shown). Moreover, entry probability into the exit zone during the probe trial was greater in $\mathrm{IH}_{\text {MnTMPyP }}\left(\mathrm{IH}_{\text {Saline }}=\right.$ $4.33 \pm 0.63 \%, \quad \mathrm{IH}_{\text {MnTMPyP }}=10.32 \pm 1.26 \% ; p=0.0005$; Fig. 5D). These data indicated that scavenging IH-derived superoxide anion prevented the reduction in the obligatory subunit of the NMDAr, prevented the loss of LTPTBS, and mitigated behavioral deficits caused by $\mathrm{IH}$.

\section{Discussion}

Our study establishes a role for IH-dependent HIF1a signaling in impairing hippocampal neurophysiology that supports spatial memory. Consistent with previous reports indicating that $\mathrm{IH}$ impacts spatial memory (Row et al., 2002; Gozal et al., 2003), we observed that IH disrupted performance in the Barnes maze. The cognitive disruptions we observed coincided with enhanced nuclear HIF1a in the hippocampus, a shift toward a pro-oxidant state, and impairment to NMDAr-dependent LTP. We found that either heterozygosity in HIF1a and 

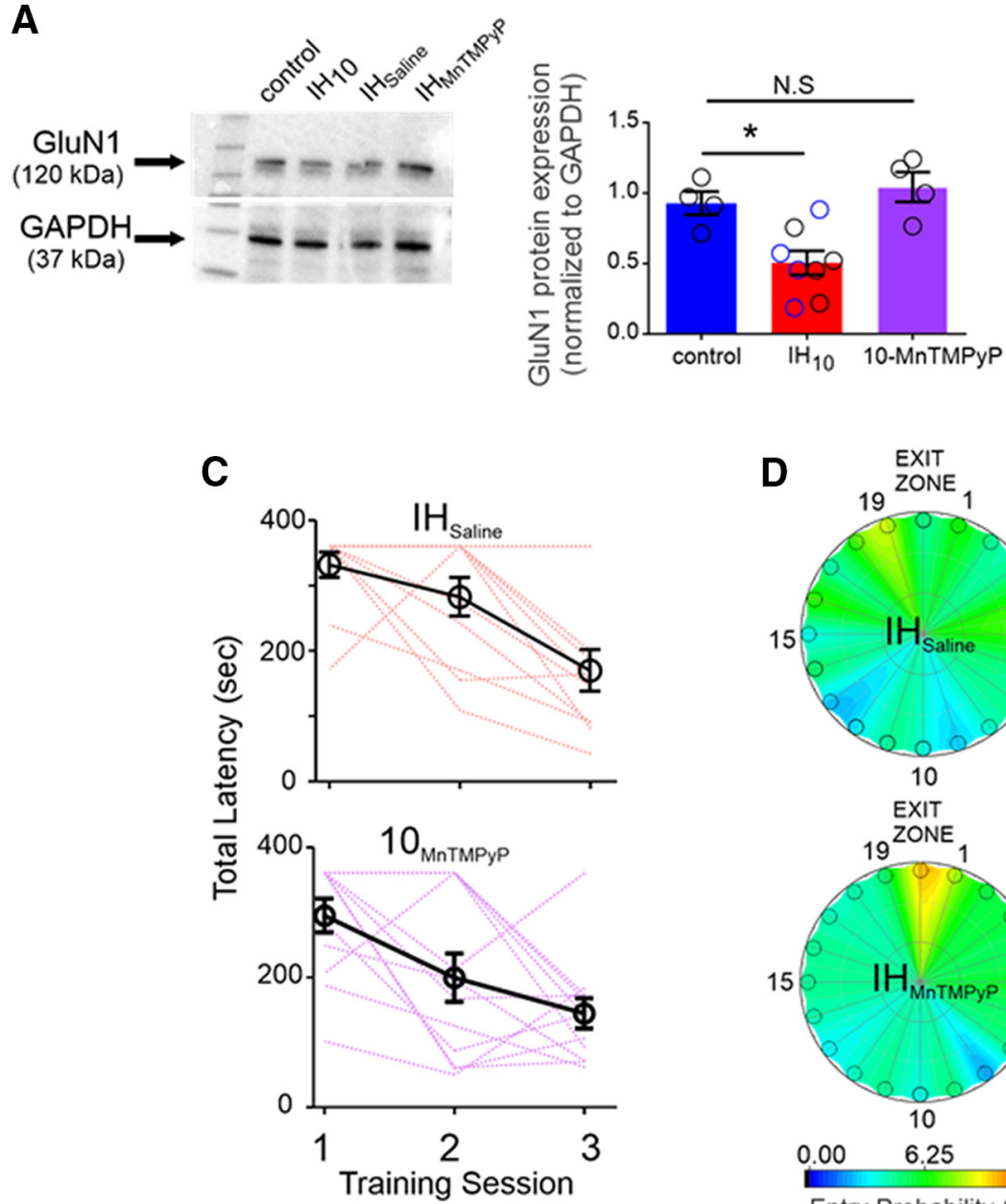
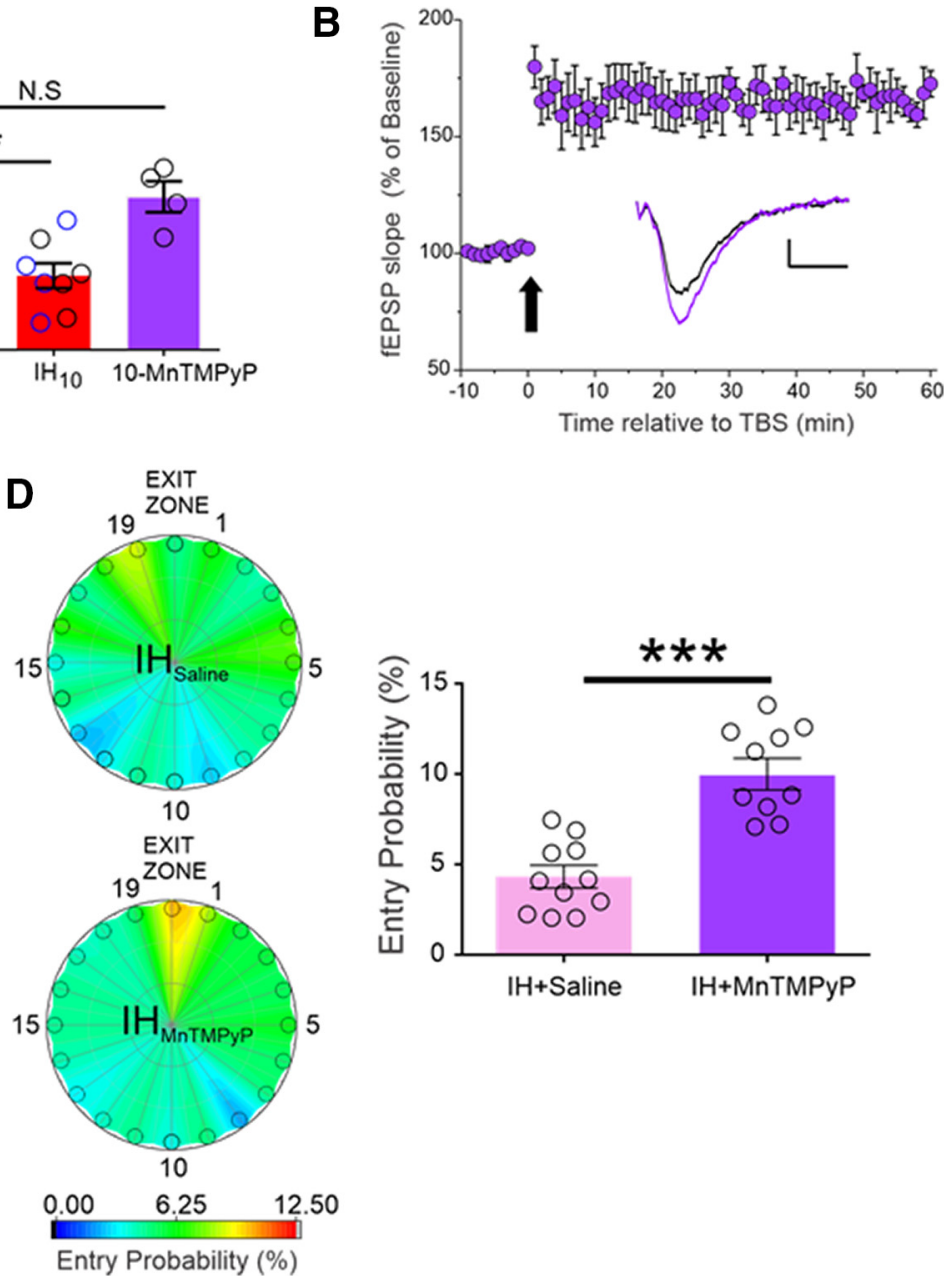

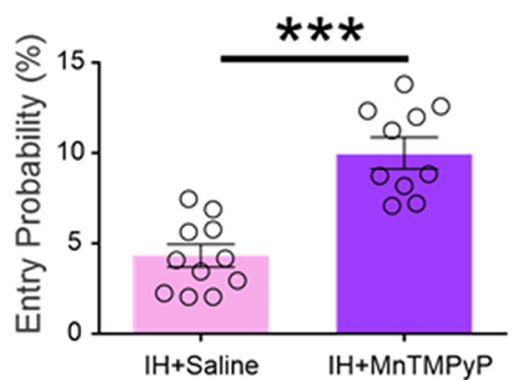

$\mathrm{IH}+$ Saline

Figure 5. Antioxidant treatment mitigates the IH-dependent effects on GluN1 expression, LTP $\mathrm{TBS}_{\text {, }}$ and performance in the Barnes maze. $\boldsymbol{A}$, left, Representative Western blottings of GluN1 and GAPDH from Control, $\mathrm{IH}_{10}$, wild-type mice treated with saline during $10 \mathrm{~d}$ of $\mathrm{IH}$ (i.e., vehicle control exposed to $\mathrm{IH}$, IH $\left.\mathrm{IH}_{\text {Saline }}, n=4\right)$, wild-type mice treated with MnTMPyP during $10 \mathrm{~d}$ of $\mathrm{IH}\left(\mathrm{IH} \mathrm{MnTMPyP}_{\mathrm{P}}\right.$ ). Right, Normalized GluN1 protein expression was examined in control $(n=4), \mathrm{IH}_{10}(n=4), \mathrm{IH}_{\text {Saline }}(n=4)$, IH MnTMPyP $(n=4)$. No difference in GluN1 was evident between $\mathrm{IH}_{10}$ (open black circles in $\mathrm{IH}_{10}$ label) and $\mathrm{IH}_{\text {Saline }}$ (open blue circles in $\mathrm{IH}_{10}$ label); therefore, the two groups were merged into the $\mathrm{IH}_{10}$ label for comparisons to control. Comparisons revealed that GluN1 was reduced only in IH $\mathrm{H}_{10}$ and unchanged in $\mathrm{IH}_{\text {MnTMPyP. }} \boldsymbol{B}$, In hippocampal slices from $\mathrm{IH}_{\text {MnTMPyP, }} \mathrm{LTP}_{\mathrm{TBS}}(n=5)$ could be reliably evoked contrasting the effect of $\mathrm{IH}_{10}$ on LTP $\mathrm{LBS}_{\mathrm{TBS}}$ (Fig. $2 \mathrm{~B}$ ). Scale bars: $0.2 \mathrm{mV} / 10 \mathrm{~ms}$. The arrow represents the TBS protocol. $\boldsymbol{C}$, The total latency to exit the Barnes maze progressively decreased in both $\mathrm{IH}_{\text {Saline }}(n=11$, pink lines represent individual performance) and IH MnTMPyP $(n=10$, purple lines represent individual performance), suggesting that both groups could learn the exit zone location. $\boldsymbol{D}$, Heat maps of the mean entry probability across all false exits (1-19) and the exit zone during the probe trial for $\mathrm{IH}_{\text {Saline }}$ and IH $\mathrm{H}_{\mathrm{MnTMP} \text {. }}$ Comparison of entry probability into the exit zone during the probe trial reveals that $\mathrm{IH}_{\mathrm{MnTMPyP}}$ has a greater probability for entering the exit zone when compared with $\mathrm{IH}_{\text {Saline }}(p=0.006) ; * * * p<0.001, * p<0.05$; N.S., $p>0.05$.

antioxidant administration prevented the effects of $\mathrm{IH}$ on the hippocampus. Together, these findings reveal a mechanistic pathway by which $\mathrm{IH}$ such as that experienced with sleep apnea impairs mechanisms underpinning spatial memory.

Evaluating the behavioral performance in control and $\mathrm{IH}_{10}$ showed that both groups progressively improved with training, yet prominent differences were present during the probe trial. These results suggested $\mathrm{IH}$ produced modest impairments to cognitive performance and is reminiscent of mild cognitive deficits documented among individuals suffering from sleep apnea (Wallace and Bucks, 2013; Devita et al., 2017b; Leng et al., 2017). These behavioral impairments coincided with targeted loss in NMDAr-dependent LTP after IH. However, neither the behavioral deficits nor impaired synaptic potentiation was observed in $\mathrm{HIF}_{1} \mathrm{a}^{+/-}$exposed to $\mathrm{IH}$ implicating a role for $\mathrm{IH}$-dependent HIF1a signaling in these phenomena.

Although administration of the prolyl hydroxylase inhibitor, dimethyloxalylglycine (DMOG), enhances HIF1a and coincides with the suppression of hippocampal LTP (Wall et al., 2014), this pharmacological approach for enhancing HIF1a can also disrupt cellular respiration well before the activation of HIF1a-dependent pathways (Zhdanov et al., 2015). This confounds understanding how enhanced HIF1a may impact hippocampal synaptic plasticity. Our 
experiments using $\mathrm{HIF}_{1} \mathrm{a}^{+/-}$mice resolved this issue. Heterozygosity in HIF1a prevented the IH-dependent increase in NOX4, the ROS-producing enzyme transcriptionally regulated by HIF1a (Diebold et al., 2010). Increasing NOX4 would be expected to increase the production of ROS and, if left unchecked, promote a prooxidant state. Indeed, IH led to increased protein carbonylation, an indication of a shift toward a more pro-oxidant state. The HIF1a-dependent increase in pro-oxidant condition was presumably due to ROS production from the enhanced presence of NOX4. The pro-oxidant state suppressed NMDAr-dependent LTP and disrupted performance in the Barnes maze.

In agreement with a previous report (Gozal et al., 2001), our protein analyses indicated that $\mathrm{IH}$ reduced GluN1 expression, the obligatory subunit of the NMDAr. Alone, this observation could not discriminate whether the effect of $\mathrm{IH}$ on GluN1 expression reflected a reduction of the NMDAr at the glutamatergic synapse, a decline in extrasynaptic receptors, a premature degradation of GluN1 before assembly of the receptor or some combination of the three. The reduction in GluN1 was not accompanied by a reduction in PSD-95, suggesting that $\mathrm{IH}$ did not indiscriminately cause a loss of glutamatergic synapses. Following $\mathrm{IH}$, the unpotentiated fEPSP (in $\mathrm{Mg}^{2+}$-free aCSF) was less sensitive to NMDAr blockade. Together, these findings may be interpreted as indicating that $\mathrm{IH}$ remodels the glutamatergic synapse by reducing receptor expression. Such a reduction in the synaptic NMDAr would likely disrupt NMDAr-dependent LTP. However, this may not be the only avenue by which $\mathrm{IH}$ disturbs NMDAr-based physiology.

Administration of MnTMPyP during $\mathrm{IH}$ prevented both GluN1 reduction and impairment to NMDAr-dependent LTP. Similarly, in 10-HIF1a ${ }^{+/-}$, GluN1 expression and NMDAr-dependent LTP was similar to that of control. These findings together indicate that HIF1a mediated ROS production is a principal mechanism that diminishes NMDAr function. While our experiments support the possibility that $\mathrm{IH}$ causes reduced receptor expression, the conductance of the NMDAr is known to be redox sensitive (Bodhinathan et al., 2010; Kumar and Foster, 2013). Specifically, oxidation of the NMDAr attenuates NMDAr conductance (Choi and Lipton, 2000; Lipton et al., 2002; Guidi et al., 2015; Foster et al., 2017). It is, therefore, likely that some combination of oxidative modulation and downregulation of the NMDAr mediates the disrupted NMDAr physiology caused by $\mathrm{IH}$. However, we did not acutely manipulate redox state and do not know to what extent the two processes contribute $\mathrm{IH}-$ dependent effects on NMDAr activity. This remains an open question to be investigated.

Independent of the precise cause, changed NMDAr activity by $\mathrm{IH}$ likely decreases the NMDAr-dependent rise in intracellular $\mathrm{Ca}^{2+}$. While a rise intracellular $\mathrm{Ca}^{2+}$ is an important event for downstream intracellular signaling critical to LTP, it also is likely to mediate other $\mathrm{Ca}^{2+}$ dependent processes within the neuron. With respect to $\mathrm{IH}$, ROS production can increase intracellular $\mathrm{Ca}^{2+}$ via the inositol 1,4,5-trisphosphate receptor (IP3R; Yuan et al., 2008), which then serves as a positive feedback mechanism to enhance and stabilize HIF1a signaling (Prabhakar

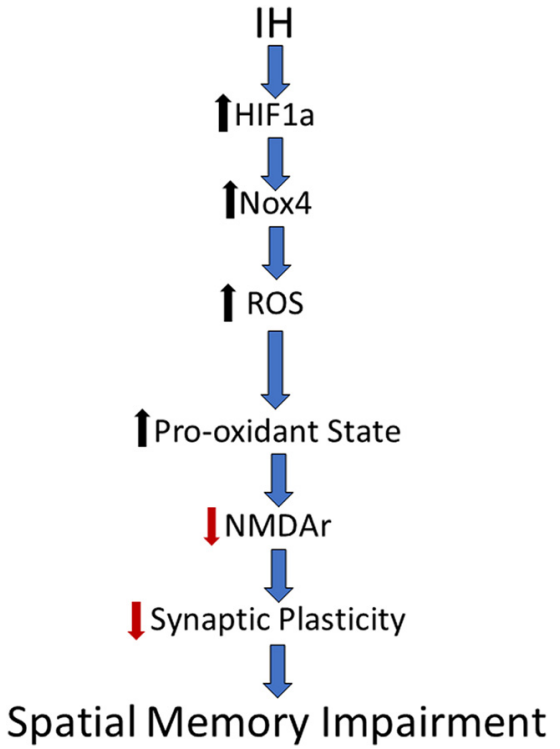

Figure 6. A mechanistic framework by which sleep apnea lowers the threshold for cognitive impairment. Schematic synthesizing our findings into a pathway by which IH promotes a prooxidant state in the hippocampus that impairs NMDAr-dependent plasticity and spatial memory.

and Semenza, 2012). As we observed that $\mathrm{IH}$ increases NOX4 and protein carbonyls in a HIF1a dependent fashion, excess elevations in intracellular $\mathrm{Ca}^{2+}$ within hippocampal cells may promote a feedforward mechanism that enhances HIF1a activity and ROS generation. Thus, the reduction of NMDAr activity may serve as a necessary phenomenon to minimize intracellular $\mathrm{Ca}^{2+}$ and prevent potential exacerbation of cellular stress if left unregulated.

The forced shift from NMDAr-dependent to NMDAr-independent forms of synaptic plasticity observed with $\mathrm{IH}$ is a phenomenon also found in models of the aging (Boric et al., 2008; Robillard et al., 2011). Thus, IH, like normal aging, limits the mechanisms normally used to support learning and memory in younger animals. Our work indicates that the HIF1a dependent pro-oxidant condition causes this aging phenotype. As the current study used younger animals (P50-P80), examining how $\mathrm{IH}$ affects mechanisms of learning and memory in aged subjects will be important to resolve.

In conclusion, we have identified an important pathway by which IH-dependent HIF1a signaling causes a pro-oxidant state that destabilizes hippocampal synaptic plasticity and disrupts spatial memory. We propose that these observations establish a mechanistic framework by which sleep apnea may lower of the threshold for cognitive impairment (Fig. 6). This mechanism may contribute to the emergence of neurologic diseases associated with untreated sleep apnea.

\section{References}

Bodhinathan K, Kumar A, Foster TC (2010) Intracellular redox state alters NMDA receptor response during aging through $\mathrm{Ca} 2+/$ calmodulin-dependent protein kinase II. J Neurosci 30:1914-1924. 
Boric K, Muñoz P, Gallagher M, Kirkwood A (2008) Potential adaptive function for altered long-term potentiation mechanisms in aging hippocampus. J Neurosci 28:8034-8039.

Cha J, Zea-Hernandez JA, Sin S, Graw-Panzer K, Shifteh K, Isasi CR, Wagshul ME, Moran EE, Posner J, Zimmerman ME, Arens R (2017) The effects of obstructive sleep apnea syndrome on the dentate gyrus and learning and memory in children. $J$ Neurosci 37:4280-4288.

Choi YB, Lipton SA (2000) Redox modulation of the NMDA receptor. Cell Mol Life Sci 57:1535-1541.

Chou YT, Zhan G, Zhu Y, Fenik P, Panossian L, Li Y, Zhang J, Veasey S (2013) C/EBP homologous binding protein (CHOP) underlies neural injury in sleep apnea model. Sleep 36:481-492.

Christakis DA, Ramirez JS, Ramirez JM (2012) Overstimulation of newborn mice leads to behavioral differences and deficits in cognitive performance. Sci Rep 2:546.

Devita M, Montemurro S, Ramponi S, Marvisi M, Villani D, Raimondi MC, Rusconi ML, Mondini S (2017a) Obstructive sleep apnea and its controversial effects on cognition. J Clin Exp Neuropsychol 39:659-669.

Devita M, Montemurro S, Zangrossi A, Ramponi S, Marvisi M, Villani D, Raimondi MC, Merlo P, Rusconi ML, Mondini S (2017b) Cognitive and motor reaction times in obstructive sleep apnea syndrome: a study based on computerized measures. Brain Cogn 117:26-32.

Diebold I, Petry A, Hess J, Görlach A (2010) The NADPH oxidase subunit NOX4 is a new target gene of the hypoxia-inducible factor1. Mol Biol Cell 21:2087-2096.

Foster TC, Kyritsopoulos C, Kumar A (2017) Central role for NMDA receptors in redox mediated impairment of synaptic function during aging and Alzheimer's disease. Behav Brain Res 322:223-232.

Gildeh N, Drakatos P, Higgins S, Rosenzweig I, Kent BD (2016) Emerging co-morbidities of obstructive sleep apnea: cognition, kidney disease, and cancer. J Thorac Dis 8:E901-E917.

Goldbart A, Cheng ZJ, Brittian KR, Gozal D (2003) Intermittent hypoxia induces time-dependent changes in the protein kinase $B$ signaling pathway in the hippocampal CA1 region of the rat. Neurobiol Dis 14:440-446.

Gozal D, Daniel JM, Dohanich GP (2001) Behavioral and anatomical correlates of chronic episodic hypoxia during sleep in the rat. $\mathrm{J}$ Neurosci 21:2442-2450.

Gozal D, Row BW, Gozal E, Kheirandish L, Neville JJ, Brittian KR, Sachleben LR Jr, Guo SZ (2003) Temporal aspects of spatial task performance during intermittent hypoxia in the rat: evidence for neurogenesis. Eur J Neurosci 18:2335-2342.

Guidi M, Kumar A, Foster TC (2015) Impaired attention and synaptic senescence of the prefrontal cortex involves redox regulation of NMDA receptors. J Neurosci 35:3966-3977.

lyer NV, Kotch LE, Agani F, Leung SW, Laughner E, Wenger RH, Gassmann M, Gearhart JD, Lawler AM, Yu AY, Semenza GL (1998) Cellular and developmental control of O2 homeostasis by hypoxia-inducible factor 1 alpha. Genes Dev 12:149-162.

Khuu MA, Pagan CM, Nallamothu T, Hevner RF, Hodge RD, Ramirez JM, Garcia AJ 3rd (2019) Intermittent hypoxia disrupts adult neurogenesis and synaptic plasticity in the dentate gyrus. J Neurosci 39:1320-1331.

Kumar A, Foster TC (2013) Linking redox regulation of NMDAR synaptic function to cognitive decline during aging. J Neurosci 33:15710-15715

Leng Y, McEvoy CT, Allen IE, Yaffe K (2017) Association of sleep-disordered breathing with cognitive function and risk of cognitive impairment: a systematic review and meta-analysis. JAMA Neurol 74:1237-1245.

Lipton SA, Choi YB, Takahashi H, Zhang D, Li W, Godzik A, Bankston LA (2002) Cysteine regulation of protein function-as exemplified by NMDA-receptor modulation. Trends Neurosci 25:474-480.
Macey PM, Prasad JP, Ogren JA, Moiyadi AS, Aysola RS, Kumar R, Yan-Go FL, Woo MA, Albert Thomas M, Harper RM (2018) Sexspecific hippocampus volume changes in obstructive sleep apnea. Neuroimage Clin 20:305-317.

Nair D, Dayyat EA, Zhang SX, Wang Y, Gozal D (2011) Intermittent hypoxia-induced cognitive deficits are mediated by NADPH oxidase activity in a murine model of sleep apnea. PLoS One 6: e19847.

Payne RS, Goldbart A, Gozal D, Schurr A (2004) Effect of intermittent hypoxia on long-term potentiation in rat hippocampal slices. Brain Res 1029:195-199.

Peng YJ, Prabhakar NR (2003) Reactive oxygen species in the plasticity of respiratory behavior elicited by chronic intermittent hypoxia. J Appl Physiol 94:2342-2349.

Peng YJ, Yuan G, Ramakrishnan D, Sharma SD, Bosch-Marce M, Kumar GK, Semenza GL, Prabhakar NR (2006) Heterozygous HIF1alpha deficiency impairs carotid body-mediated systemic responses and reactive oxygen species generation in mice exposed to intermittent hypoxia. J Physiol 577:705-716.

Prabhakar NR, Semenza GL (2012) Adaptive and maladaptive cardiorespiratory responses to continuous and intermittent hypoxia mediated by hypoxia-inducible factors 1 and 2. Physiol Rev 92:967-1003.

Robillard JM, Gordon GR, Choi HB, Christie BR, MacVicar BA (2011) Glutathione restores the mechanism of synaptic plasticity in aged mice to that of the adult. PLoS One 6:e20676.

Row BW, Kheirandish L, Neville JJ, Gozal D (2002) Impaired spatial learning and hyperactivity in developing rats exposed to intermittent hypoxia. Pediatr Res 52:449-453.

Semenza GL, Prabhakar NR (2015) Neural regulation of hypoxia-inducible factors and redox state drives the pathogenesis of hypertension in a rodent model of sleep apnea. $J$ Appl Physiol 119:1152-1156.

Sforza E, Celle S, Saint-Martin M, Barthélémy JC, Roche F (2016) Hippocampus volume and subjective sleepiness in older people with sleep-disordered breathing: a preliminary report. J Sleep Res 25:190-193.

Song X, Roy B, Kang DW, Aysola RS, Macey PM, Woo MA, Yan-Go FL, Harper RM, Kumar R (2018) Altered resting-state hippocampal and caudate functional networks in patients with obstructive sleep apnea. Brain Behav 8:e00994.

Varga AW, Kishi A, Mantua J, Lim J, Koushyk V, Leibert DP, Osorio RS, Rapoport DM, Ayappa I (2014) Apnea-induced rapid eye movement sleep disruption impairs human spatial navigational memory. J Neurosci 34:14571-14577.

Wall AM, Corcoran AE, O'Halloran KD, O'Connor JJ (2014) Effects of prolyl-hydroxylase inhibition and chronic intermittent hypoxia on synaptic transmission and plasticity in the rat CA1 and dentate gyrus. Neurobiol Dis 62:8-17.

Wallace A, Bucks RS (2013) Memory and obstructive sleep apnea: a meta-analysis. Sleep 36:203-220.

Xie H, Leung KL, Chen L, Chan YS, Ng PC, Fok TF, Wing YK, Ke Y, Li AM, Yung WH (2010) Brain-derived neurotrophic factor rescues and prevents chronic intermittent hypoxia-induced impairment of hippocampal long-term synaptic plasticity. Neurobiol Dis 40:155162.

Yuan G, Nanduri J, Khan S, Semenza GL, Prabhakar NR (2008) Induction of HIF-1alpha expression by intermittent hypoxia: involvement of NADPH oxidase, Ca2+ signaling, prolyl hydroxylases, and mTOR. J Cell Physiol 217:674-685.

Zhang SX, Wang Y, Gozal D (2012) Pathological consequences of intermittent hypoxia in the central nervous system. Compr Physiol 2:1767-1777.

Zhdanov AV, Okkelman IA, Collins FW, Melgar S, Papkovsky DB (2015) A novel effect of DMOG on cell metabolism: direct inhibition of mitochondrial function precedes HIF target gene expression. Biochim Biophys Acta 1847:1254-1266. 